\title{
Two Types of Discrimination: The Familiar and the Forgotten
}

\author{
Deborah Hellman $\dagger$
}

This Essay argues that current Equal Protection doctrine fails to recognize an important conceptual distinction between two types of discrimination. Current doctrine is inadequate, according to the author, because it treats all discrimination cases as if they were instances of only one of these types. As a result, the Supreme Court mistreats discrimination cases of the forgotten variety. The author draws a distinctions between proxy and non-proxy discrimination. Proxy discrimination uses the classification in the law as a means to reach a set of persons with a different, correlated trait. Non-proxy discrimination, by contrast, aims at the set defined by the classification itself. Because each has a distinct aim, each requires an examination of different moral issues. The author argues that current Equal Protection doctrine is suited for proxy discrimination only. Non-proxy cases are forced into an inappropriate doctrinal scheme with two unfortunate results. First, the Court focuses its attention on irrelevant issues and second, the Court fails to address the real and important issues that cases of non-proxy discrimination present. At the close of the Essay, the author sketches a new theory for nonproxy cases and demonstrates how this theory casts familiar issues like affirmative action and single-sex education in a new light.

\section{INTRODUCTION}

Equal Protection doctrine embodies the Supreme Court's theory of wrongful discrimination." This Essay will argue that the theory is

Copyright @ 1998 California Law Review, Inc.

$\dagger$ Assistant Professor, University of Maryland School of Law; B.A., Dartmouth College; M.A., Columbia University; J.D., Harvard Law School. I want to thank Robert Post and William Richman for their thoughtful comments on a draft of this Essay and Robert Gaumont for excellent research help.

1. Andrew Koppelman claims that the Supreme Court's "own justifications for its interpretations of the equal protection clause are too thin, fragmentary, and inconsistently followed in its decisions to be properly called a "theory."' ANDrew Koppelman, ANTIDISCRIMINATION LAW AND Social EQUALITY 15 (1996). I agree that the Court's justifications are both thin and contradictory. However, by looking at the doctrinal framework the Court employs to address Equal Protection cases, we can glean the basic commitments that undergird its approach. See infra Part Il.A. 
conceptually flawed. It fails to recognize an important distinction between two types of discrimination cases. The challenged laws use classifications in two distinct ways. In what follows, I argue that the theory the Court employs is suitable for only one of these types. As a result, the Court mistreats discrimination cases of the neglected, or forgotten, variety.

Laws and policies, in order to carry out myriad objectives, must draw distinctions. Many of these distinctions are banal: If one's income is over a specified amount, one must pay a higher percent of such income in federal taxes than if one's income is below that level. Others are morally and constitutionally problematic: Virginia's state-run military college, Virginia Military Institute ("VMI"), had until recently a policy of admitting only men. Every classificatory law could, in principle, present an Equal Protection issue. The first law treats those with incomes above the bracket differently than those with incomes below it; the second law treats women differently than men.

One can divide these laws that classify into two broad categories: proxy and non-proxy. In instances of classification by proxy or "proxy discrimination" (hereinafter using the term "discrimination" in the non-pejorative sense), the trait by which the statute classifies is used as a proxy for another trait. For example, if a law firm refuses to hire women lawyers because the firm management believes that women are less aggressive than men, then sex is a proxy for aggressiveness. In contrast, Wellesley College's practice of admitting only women is an instance of non-proxy discrimination. The school refuses to admit men not because it sees sex as a stand-in for other traits, but rather to maintain a single-sex educational environment.

This Essay makes two claims. First, there is an important conceptual difference between proxy and non-proxy discrimination. Because each uses classifications in a distinct way and for a distinct purpose, each necessitates its own type of moral inquiry. Second, the theory of wrongful discrimination expressed in the Supreme Court's Equal Protection doctrine is built around the conceptual problems and moral issues of only one of these types. The Court's theory is a theory for evaluating when proxy discrimination is wrong. As a consequence, when faced with instances of non-proxy discrimination, the Court lacks the appropriate analytical tools to address the issues presented. This does not mean that the Court necessarily reaches a bad result. Rather, its opinion fails to address the real and important questions that non-proxy cases pose. Therefore, the opinion is likely to seem especially ad hoc or oddly reasoned as the writer valiantly tries to force the case into an inappropriate 
conceptual schema. Two recent cases, Romer v. Evans ${ }^{2}$ and United States $v$. Virginia, ${ }^{3}$ represent prominent examples of this problem.

This distinction between proxy and non-proxy discrimination is fresh. Cases and commentary occasionally speak of proxies and perceive that many classificatory laws use one trait as a means to reach another. But missing thus far has been the understanding that only some classificatory laws work this way. This Essay highlights the importance of the distinction between proxy and non-proxy discrimination. It argues that because each has a distinct aim, the moral and legal permissibility of each rests on different issues. The recognition of these differences should lead the Court to modify its Equal Protection doctrine. Current doctrine may work for proxy cases, but non-proxy cases need a new theory.

At the outset, let me make clear that I am not claiming that the Court's approach to proxy discrimination is the morally correct approach. Rather, I argue that its theory of wrongful discrimination is reasonable or apt for proxy discrimination. It addresses the issues such cases present and offers a resolution of them.

Part I describes the conceptual distinction between proxy and nonproxy discrimination. Using this distinction, Part II demonstrates that the Court's anti-discrimination doctrine is appropriate for cases of proxy discrimination only. Part III then turns from theory to practice and examines some non-proxy cases which the Court has handled inadequately. Part IV describes the origins of current doctrine and Part V describes how my critique of that doctrine elaborates on the work of others. Part VI introduces a new theory for non-proxy cases. Finally, Part VII demonstrates how this new theory makes different aspects of Equal Protection cases salient, significantly transforming our analysis of controversial practices like affirmative action and single-sex education.

\section{I}

\section{The Taxonomy of Classifications}

\section{A. Proxy Discrimination}

Laws and policies that employ proxies are commonplace, appearing in both public and private life. Suppose, for example, a law firm decides to hire as new associates only those law school graduates in the top $10 \%$ of their law school classes. This hiring policy clearly discriminates. The firm treats such graduates differently, in this case more favorably, than those not in the top $10 \%$. This is a case of proxy discrimination because the firm selects the group identified by the classification, those

2. 116 S. Ct. 1620 (1996).

3. 116 S. Ct. 2264 (1996). 
in the top $10 \%$ of the class, in order to reach another group: those who will be effective lawyers. I call this form of discrimination "proxy discrimination" because the firm uses one identifying characteristic as a proxy for another.

The proxy is a means to an end. The law firm partners in the above example care about hiring law graduates in the top of the class because they believe that the top graduates will make better lawyers than their classmates. For the most part, the firm has no other independent interest in having a firm filled with top graduates. If the firm touts this information to prospective clients, it does not show that having top graduates is valuable in itself. Rather, it shows that the clients share the belief that grades are a good proxy for legal ability.

Since proxy discrimination is merely a tool used to identify a class of persons or things with a different identifying trait, the "target," proxy discrimination is generally employed in instances where the target is somewhat elusive. The law firm example is illustrative. While it would be best for the law firm simply to hire the law school graduates who have the greatest legal ability, this is not a straightforward task. Three related problems hamper identification of the skills and abilities that make someone a good lawyer. First, although we may know a good lawyer when we see her, we are often hard-pressed to articulate what qualities or characteristics account for this legal talent. Second, some identifiable legal abilities, such as good judgment, are complex and thus difficult to test for in job applicants. Third, even those qualities that can be identified and sensibly evaluated, writing ability, for example, may be costly to assess, at least in the initial screening phase. The law firm thus adopts the top $10 \%$ of the law school class policy as a fourth best, but nonetheless cost-effective, proxy for legal skill.

Instances of proxy discrimination are ubiquitous. But simply because a law or policy employs a proxy does not yet determine whether the law or policy at issue is morally problematic. The above example is an instance of the benign use of a proxy. In contrast, were the law firm to use sex as the first screening device on the theory that women are less assertive than men and consequently make less effective lawyers, it would be both morally and legally troublesome.

\section{B. Non-Proxy Discrimination}

In instances of non-proxy discrimination, the classification is its own end. A good example of non-proxy discrimination is the admissions practice of a women's college. Wellesley College discriminates in its admissions policy on the basis of sex. But unlike the hypothetical law firm which will hire only men as a means to getting assertive lawyers, the Wellesley policy is not calculated at selecting students with a 
constellation of traits other than sex. The college does not exclude men because it wants students who are nurturing, sensitive, or any other characteristic thought to be positively correlated with the female sex. Rather, the school simply desires a single-sex educational environment. The policy aims directly at the set of individuals it seeks.

Although the above contrast might seem to suggest that non-proxy discrimination might be more benign than proxy discrimination, this is not necessarily the case. Both come in pernicious and benign forms. In fact, it is probably pernicious non-proxy discrimination that presents the paradigmatic case of wrongful discrimination. For example, when the University of Texas Law School had a policy of admitting no AfricanAmerican applicants in accordance with state law, ${ }^{4}$ this constituted wrongful non-proxy discrimination on the basis of race. The state legislators who enacted the policy did not exclude blacks in order to reach a different set of persons, such as those who will make poor lawyers, on the view that such traits are positively correlated with race. Rather, the purpose was simply to exclude blacks from the law school. The classification defined the set of persons desired.

\section{The Malleability of the Classifications}

The conceptual distinction I delineate, between the proxy use of a classification to reach a target class and the non-proxy use of a classification to reach the class it itself identifies, is sometimes unclear in practice. For example, the exclusion of black men from jury service in West Virginia at issue in the 1880 case, Strauder $v$. West Virginia, ${ }^{5}$ might fit into either class. If the goal of the statute was to select only responsible citizens for jury service, ${ }^{6}$ and the statute was predicated on the belief that whites were in general more responsible than blacks, then the statute represents an instance of proxy discrimination. If, on the other hand, the statute's purpose was to prevent blacks from serving on juries (i.e., if the classification is its own end), it represents an instance of non-proxy discrimination. My intuition is that the Strauder statute is an instance of non-proxy racial discrimination. One way to test the accuracy of that intuition is by pressing on the factual premise of the proxydiscrimination conception. If the Strauder statute were an instance of proxy discrimination, one would expect the legislators to be amenable to revising it were the factual claim that blacks are less responsible than whites disproved. To the extent that we believe that the legislators would

4. See Sweatt v. Painter, 339 U.S. 629, 631 (1950).

5. 100 U.S. $303(1880)$.

6. Remember that, in 1880 , states permissibly limited jury service to men, property owners, and the literate on the grounds that these qualifications were rational proxies for the qualities of character necessary for jury service. See id. at $\mathbf{3 1 0}$. 
adopt the statute notwithstanding such a showing, we believe that the law presents an instance of non-proxy discrimination.

While not all classificatory statutes or policies will be easy to describe as instances of both proxy and non-proxy discrimination, many will be. This malleability indicates that the task of determining which type of discrimination a law or policy instantiates is interpretative. Proxy and non-proxy discrimination are conceptually distinct forms, employed for different purposes and accompanied by different moral concerns. However, the language of the statute or policy itself does not always make the form explicit. It is therefore often necessary to reconstruct the plausible purpose of the statute, or to intuit what may be morally troubling about its deployment, to arrive at a rendering of the law as either proxy or non-proxy discrimination.

Some cases present easy interpretive tasks. For example, the Social Security Act at issue in Califano v. Webster ${ }^{7}$ allowed women to exclude three more years of low-wage jobs from the computation of average wage used in determining social security benefits than it allowed men. The apparent purpose of the provision was to compensate women for discrimination in the labor market. ${ }^{8}$ Thus, the Social Security Act used sex as a proxy for past discrimination. Women were identified and disaggregated from the larger set of all people as a means of identifying that set of persons who had previously suffered discrimination on the basis of sex in wages or employment opportunities.

Analogously, the antimiscegenation law at issue in Loving $v$. Virgini $a^{9}$ is an easily identifiable instance of non-proxy discrimination. The statute forbade the marriage of blacks to whites, the mixing of the races. ${ }^{10}$ Neither the classification "blacks"-or "Negroes" as the statute actually read-nor "whites" was used to reach a class of persons other than that described by the classification itself. Rather, the separation delineated by the classificatory act was the explicit aim of the law.

Other classificatory laws or policies are more difficnlt to interpret. The broadcast licensing scheme at issue in Metro Broadcasting, Inc. $v$. $F C C^{11}$ provides a good example. Focusing on the contested provisions,

7. 430 U.S. 313 (1977) (upholding the disputed provision of the Social Security Act).

8. See id. at 318 .

9. 388 U.S. 1 (1967).

10. Actually the statute forbade the marriage of whites to non-whites but permittcd intermarriage between non-whites-between "Negroes" and "Orientals," for example. See id. at 11. In fact, "Negroes" may not constitute a race, as that term is understood scientifically. See, e.g., K. Anthony Appiah, Race, Culture, Identity: Misunderstood Connections, in K. ANThony AppiAH \& Amy Gutmann, Color Conscious 30-74 (1996).

11. 497 U.S. 547 (1990) (upholding the use of race as a plus-factor in awarding broadcast lieenses and upholding the provision giving minorities the right to purchase licenses at distress sales). The Court had applied intermediate scrutiny to this benign use of race as a plus-factor. This part of its 
which treated the race of the bidder as a plus-factor in the competition for broadcast licenses, we can plausibly describe them as either proxy or non-proxy discrimination. If we see the purpose of the statute as encouraging programming diversity, as the majority of the Court did, ${ }^{12}$ then race is a proxy for viewpoint. In order to achieve diverse programming, the statute encourages racial diversity in ownership. It picks out a set of racially diverse persons in order to get a set of persons with diverse interests and outlooks. ${ }^{13}$

Alternatively, one can see racial diversity in broadcast ownership as its own goal. Rather than encouraging racial diversity in order to foster viewpoint or programming diversity, as in proxy discrimination, the statute might seek racial diversity in broadcast ownership to achieve a spectrum that looks like America and thus to enhance political legitimacy. Similarly, President Clinton's pledge in his first term to appoint a cabinet that "looks like America" can be described alternatively as proxy or non-proxy discrimination. ${ }^{14}$ Either Clinton sought racial diversity in order to get a different species of diversity, viewpoint, experience, and so on-proxy discrimination-or he sought racial diversity for its own sake-non-proxy discrimination. The reason for seeking racial diversity in cabinet appointments was that it would promote the appearance of inclusiveness, an important goal for the President to seek. Something similar could be at work in Metro Broadcasting.

As the above discussion illustrates, when I claim that in non-proxy cases the sorting achieved by the classificatory statute or policy is its own goal, I do not mean to claim that it is sought for no reason. Clearly there are reasons for instances of non-proxy discrimination. The administrators of Wellesley College no doubt believe there are important educational benefits to single-sex education, particularly for women. In both proxy and non-proxy cases, there are reasons for the discrimination. What non-proxy cases lack is what I term the "target." In the proxy discrimination case, the law or policy uses the proxy in order to reach the target: People who have some other trait or characteristic. For example, race, sex, or grade-point average is used to reach people who have an outsider viewpoint, assertiveness, or legal ability.

holding was later specifically overruled. See Adarand Constructors, Inc. v. Pena, 515 U.S. 200, 226 (1995).

12. See Metro Broad., 497 U.S. at 552-58.

13. Actually, the statute does not mandate racial diversity, but rather facilitates or encourages it by use of the plus-factor. This difference (between a quota and a plus-factor), while significant to the court, see, e.g., University of California Regents v. Bakke, 438 U.S. 265 (1978), is not significant to my purpose of distingnishing between proxy and non-proxy cases.

14. See Irwin Arieff, Clinton Cabinet Blends Party Doctrine with Reformist Zeal, Reuters LiBR. REP., Dec. 23, 1992, available in LEXIS, News Library, Wires File; see also Gwenn Ifill, The Transition; Clinton's High-Stakes Shuffle to Get the Right Cabinet Mix, N.Y. Times, Dec. 21, 1992, at A1; Judy Mann, A Cabinet That Looks Like America?, WASH. PosT, Dec. 18, 1992, at E3. 
In non-proxy cases, the classification has no target; its aim is the sorting it itself achieves. But both types of discrimination are supported by reasons. In the case of proxy discrimination, the reason relates to the target: It is a reason for aiming at that target. In non-proxy cases, the reason relates to the original classification: It is a reason for classifying in that way.

\section{The Moral Issues}

Earlier, I argued that distinguishing between proxy and non-proxy cases is an interpretive task. In order to determine whether a classificatory law or policy is an instance of proxy or non-proxy discrimination, one must look at both the aim of the statute and the moral issues it occasions. Therefore, the first question is: At what sorting did the statute aim?

The second question is: What moral concerns are raised by the use of the classification? In proxy cases, moral issues are raised at two places. First, we might wonder whether use of the proxy is an appropriate way to reach the target. Second, we may question whether the target itself is morally permissible. In non-proxy cases there is only one stage to the moral inquiry: Is it appropriate to classify in this way? In proxy cases, we examine both means and end, whereas in non-proxy cases we examine only the end.

This distinction gives the inquiry a very different flavor, as a comparison of cases exhibits. Suppose a small litigation firm seeking aggressive lawyers decides to interview and hire only men on the basis that men are generally more aggressive than women and given limited time and money this sorting mechanism will be cost effective. What bothers us about this practice? ${ }^{15}$

First, we may worry that the factual predicate of the policy is mistaken. Women may not actually be any less aggressive than men, but may be considered so due to outdated and mistaken stereotypes. If so, the policy may be inefficient and unhelpful to yielding aggressive lawyers. Second, even if it is efficient because men are on average more aggressive than women, some aggressive women will not have employment opportunities. We may worry about the unfairness to these "false negatives." Third, timid men, "false positives," get a benefit from this stereotype that may also seem unfair. Fourth, the over- and underinclusiveness of the generalization burdens a group already

15. Not every one is bothered. See Richard A. EpSTEIN, Forbidden Grounds: The CASE Against Employment Discrimination Laws (1992) (arguing for the repeal of antidiscrimination law in the employment context on the grounds that there is no moral wrong that needs righting by such legislation and that market mechanisms will correct the worst cases, leaving minorities and women with adequate job opportunities). 
disadvantaged in our society, women, and benefits a group already advantaged, men. Fifth, the efficiency of a stereotype may be due to illegitimate restrictions on the opportunities open to women in the past or other forms of social conditioning that may themselves be suspect.

Note that the aim of hiring aggressive lawyers in itself seems morally unproblematic. In proxy discrimination cases, the target is often innocuous. Although proxy discrimination can raise issues regarding both the proxy and the target, the proxy is characteristically the problem. The moral issues engendered by the law firm's sex discrimination are issues of means. Is this means of using sex to find aggressiveness permissible morally, or does it treat both women and men in a way they ought not to be treated? At the risk of oversimplification, I will describe these concerns as instrumental.

Compare that case to the non-proxy discrimination at issue in Sweatt $v$. Painter. ${ }^{16}$ This discrimination raises moral concerns of a different character. First, we are concerned about the social meaning ${ }^{17}$ of separation by race in legal education. Such legally mandated segregation may express the false moral view that some people are less worthy of respect than others. Second, we worry that an important good is denied to some people. And third, we are uneasy if the classificatory policy burdens a socially or economically disadvantaged group.

These concerns are responsive to the segregation achieved through the classification itself. They focus on its social significance and on whether the allocation of benefits and burdens thereby produced is fair. Again at the risk of oversimplification, I will call these non-instrumental concerns.

II

The Court's Theory as a Theory of Proxy Discrimination

\section{A. The Court's Theory}

By painting Equal Protection case law with a broad brush, I will show that its exposition of impermissible discrimination is only suitable for proxy discrimination cases. The Supreme Court has adopted a theory of when a law violates the Equal Protection Clause that focuses on the trait or characteristic that is the basis of the classification. ${ }^{18}$ The Court then sorts these cases using this classification into three categories:

16. 339 U.S. 629 (1950); see supra note 4 and accompanying text.

17. For an account of "social meaning," see, e.g., Lawrence Lessig, The Regulation of Social Meaning, 62 U. CHI. L. Rev. 943 (1995).

18. Classificatory laws that burden an important interest, termed "fundamental," are also subject to strict scrutiny. However, this fundamental interests strand of Equal Protection case law is not primarily concerned with discrimination and, as such, has often been criticized as "substantive equal protection." See Gerald Gunther \& KathleEN M. Sullivan, Constitutional Law 84041 (13th ed. 1997). 
those that require strict scrutiny, those that require intermediate scrutiny, and those that need only be justified on a rational basis. The degree of suspectness of the classification determines the level of court review.

The level of scrutiny determines which test the classificatory law must pass. Strict scrutiny, appropriate for a law that classifies on the basis of race, requires that the classification be "narrowly tailored" to achieve "a compelling governmental interest."19 Intermediate scrutiny, applied in sex discrimination cases, requires that the law be "substantially related" to the achievement of "an important governmental objective." ${ }^{20}$ Finally, where the classification is not suspect at all, the law must only be "rationally related" to a legitimate governmental objective. ${ }^{21}$

Debate and disagreement exist at each of the joints of this analysis. For example, controversies have erupted over what level of scrutiny is required for particular classifications; what governmental interests can count as legitimate, important, or compelling; and whether rationality review has teeth. However, looking at this doctrine from a distance, two features are salient. First, the analysis of whether a classificatory law violates the Equal Protection Clause requires an evaluation of the importance and legitimacy of the objective to be served. Second, the analysis mandates an assessment of the relationship between the classification and the objective. Although what courts define as the "objective" has been somewhat confused, the two-component analysis with its emphasis on the relation between classification and objective is well suited for proxy discrimination issues.

\section{B. Why It Is a Theory Exclusively for Proxy Discrimination}

\section{Doctrinal Form}

Each of the three tests described above requires some review of the fit between the classification employed in the law and its objective. The classification must be "narrowly tailored" or "substantially related" to pass the heightened standards of review. This emphasis on fit and relation conforms to the structure of proxy discrimination and bespeaks a concern with the type of moral issues that this form of discrimination raises.

The Court understands the requirements of being "narrowly tailored" and "substantially related" as concerning over- and underinclusiveness. For example, in Richmond v. J. A. Croson Co., ${ }^{22}$ Justice O'Connor, for the Court, rejected a minority set-aside program because

19. Adarand Constructors, lnc. v. Pena, 515 U.S. 200, 235 (1995).

20. Craig v. Boren, 429 U.S. 190, 197 (1976).

21. Massachusetts Bd. of Retirement v. Murgia, 427 U.S. 307,312 (1976).

22. 488 U.S 469 (1989). 
of insufficient evidence that the beneficiaries of the set-aside program had been the victims of discriminatory practices in the Richmond construction industry. For her, the determinative issue was that "[i]f a $30 \%$ set-aside was 'narrowly tailored' to compensate black contractors for past discrimination, one may legitimately ask why they are forced to share this 'remedial relief' with an Aleut citizen who moves to Richmond tomorrow?"23 The failure of narrow tailoring is a failure in the proxy variable, minority status, to closely track the target variable, victims of discrimination in Richmond's construction industry.

This understanding of the function of narrow tailoring is not limited to the majority. The concurring and dissenting opinions in Croson analyze whether the statute works an Equal Protection violation in this same way. For example, Stevens' concurrence emphasized both the program's over- and under-inclusiveness as its constitutional defects. ${ }^{24}$ Similarly, Marshall, in dissent, claimed that the facts of Croson satisfy even the requirement of narrow tailoring because "to suggest that the facts on which Richmond has relied do not provide a sound basis for its finding of past racial discrimination simply blinks credibility."25 Marshall thus asserted that the overlap is great between the class defined by the proxy and the target class.

Intermediate scrutiny's requirement that the classification used in the disputed statute be "substantially related" to an "important governmental objective" is similarly concerned with the degree of fit between the proxy class and an implied target class. We can unpack "substantially related" as requiring a looser fit than strict scrutiny. These cases tolerate more over- and under-inclusiveness, but not too much more. For example, in Craig v. Boren, Justice Brennan explained the lesson gleaned from the Court's sex-classification cases:

In light of the weak congruence between gender and the characteristic or trait that gender purported to represent, it was necessary that the legislatures choose either to realign their substantive laws in a gender-neutral fashion, or to adopt procedures for identifying those instances where the sex-centered generalization actually comported with fact. ${ }^{26}$

Justice Stevens, concurring in Craig, also understood the legal issue of substantial relationship to be one of fit. To Stevens, the problem with the Craig statute, which permitted women in Oklahoma to buy $3.2 \%$ beer at age 18 while men had to be 21 , was that "[t]he legislation imposes a

23. Id. at 506 (Stevens, J., concurring).

24. See id. at 515. On over-inclusiveness, Stevens objects that "[t]he class of persons benefited by the ordinance is not, however, limited to victims of such discrimination ...." Id.

25. Id. at 541 (Marshall, J., dissenting).

26. 429 U.S. 190,199 (1976). 
restraint on $100 \%$ of the males in the class allegedly because about $2 \%$ of them have probably violated one or more laws relating to the consumption of alcoholic beverages."27 This is a problem of overinclusiveness and ill-fit.

While Craig v. Boren, Richmond v. Croson Co., and other cases ${ }^{28}$ wear their conception of discrimination as ill-fit between proxy class and target class unmistakably, in still other cases, a reconstruction of the conception of discrimination used is more elusive. In part, this is due to a confusion about what is meant by the objective to which the classification relates narrowly, substantially or rationally. When a court intones strict scrutiny's formulaic requirement that the classification be "narrowly tailored to achieve a compelling governmental objective," that "objective" could designate either the target class, as it appears to in Craig and Croson, or it could denote the purpose or reason for seeking the target.

Remember that in instances of proxy discrimination there will be a proxy, a target, and a reason for seeking that target. Just as the proxy and the target are not coextensive, neither are the target and its rationale. In other words, seeking the target may not be the only way to further the purpose identified. For example, in Craig $v$. Boren, the purpose of the statute restricting the drinking of $3.2 \%$ beer was allegedly to promote traffic safety ${ }^{29}$ Clearly there are many other ways of promoting traffic safety: lower speed limits, stricter driving tests, better roads, and more traffic lights. Equal Protection doctrine does not demand that sexbased classification be substantially related to the objective qua reason. Rather, the relevant inquiry is whether the gender classification fits well enough with the target class at which it aimed: those who drink and drive.

It is this confusion between objective qua reason and objective qua target that has facilitated the Court's failure to see that non-proxy cases are a different species which require a different analysis. Since there is a reason for non-proxy classification, there is an "objective" to plug into the doctrinal test. However, by doing so, the Court subjects these nonproxy cases to an inapt conceptual inquiry which focuses our attention on the wrong moral issues. ${ }^{30}$

27. Id. at 214 (Stevens, J., concurring).

28. See, e.g., J.E.B. v. Alabama, 511 U.S. 127, 129 (1994) (holding that "gender, like race, is an unconstitutional proxy for juror competence and impartiality").

29. See Craig, 429 U.S. at 199.

30. See infra Part III. 


\section{Moral Issues Addressed}

The Court's theory of wrongful discrimination is easily identified as a theory for proxy discrimination. Its form tracks that of proxy discrimination and its moral focus aims at the same moral issues that proxy discrimination presents. The moral concerns raised by proxy cases, which I termed instrumental, are issues of means. For example, may a law or policy use a particular trait to identify persons with a different trait, or will doing so unfairly burden the false positives or unfairly benefit the false negatives? As we see from the examples of Craig $v$. Boren and Richmond v. Croson Co. discussed above, the moral inquiry the Court's doctrinal analysis brings forth deals with precisely such issues. Stevens worries in Craig about the unfairness to $98 \%$ of men adversely affected by the statute who would not drink and drive. O'Connor worries in Croson about the unfair benefit the Aleut resident of Richmond may derive from the minority set-aside program.

Thus, the Court's Equal Protection doctrine is a theory of proxy discrimination because it focuses our attention on these moral issues rather than others. The doctrine asks one to look at the strength of the classification as a proxy for a different, but allegedly correlative, trait.

Of course, the Court's Equal Protection doctrine also requires an inquiry into the legitimacy of the governmental objective. It is a twopart analysis: fit plus legitimacy of objective. We see the Court looking with varying degrees of scrutiny at the merits of seeking the proxy's target. In the above two cases, Craig and Croson, the target is relatively innocuous and valid reasons support the desire to seek it. For example, it certainly makes sense for Oklahoma to try to identify young drivers not yet ready for the responsibility of drinking. The desire to promote traffic safety provides a good reason for the statute to attempt to identify this target class. The fact that the Court's doctrinal treatment addresses both of these issues, the fit between the proxy and the target and the legitimacy of seeking the target itself, shows us that the Court's Equal Protection doctrine is geared to proxy discrimination and the moral issues it raises.

In order to see this more clearly, we need only think about the moral issues non-proxy cases raise. In non-proxy cases, in which the segmentation achieved by the classification is its own end, we examine whether the reasons for separating and classifying on the basis of the trait chosen provide an adequate justification for so doing. This moral inquiry into what I termed non-instrumental concerns looks at questions very different from those identified above. This inquiry is focused first on whether the separation achieves a fair distribution of benefits and second on whether the social significance of such separation is morally problematic. 
If these are the relevant moral questions of non-proxy discrimination, it is striking that the Court's Equal Protection doctrine has no doctrinal room in which to address them. The dominant inquiry of Equal Protection case law is about fit: How tight is the correlation between the trait used in the statute and its purported target? This inquiry has no place in non-proxy cases. The inquiry into the legitimacy of the target is also out of place in non-proxy cases, in which the classification does not aim at a target other than itself. Of course, in non-proxy cases, we do want to examine the moral merits of the segregation achieved by the classification, which may be analogous to looking at the legitimacy of the target. However, because of an important doctrinal misconceptiona confusion of the target of proxy discrimination with the rationale for non-proxy cases-this important inquiry is often neglected.

III

Inapt Analysis: How the Proxy Theory Mistreats THE NON-PROXY CASES

\section{A. Conceptually}

Treating non-proxy cases with the Court's Equal Protection doctrine, a proxy theory, fails because the heart of the proxy analysis is fit. Because non-proxy cases do not pose questions of fit, the main conceptual apparatus used to address the central moral issue of proxy cases simply has no relevance. Misuse of this doctrine only makes matters worse. If the Court has a theory of fit, it must find two poles to map the theory onto, something whose fit with something else is to be evaluated. The Court thus either posits a false target or inappropriately analyzes the relationship between the rationale for the classification and the classification itself using the rubric of fit.

The false target problem is the more serious. Here, the Court supplies a target for a classification that does not aim to identify any set of people apart from the set defined by the classificatory trait. For example, if one were to read Wellesley College's single-sex admissions policy as a means to admit people who are nurturing and supportive rather than as seeking to admit only women, one would posit a false target. In doing so, one simultaneously wastes time asking the wrong questions and fails to address the right ones. If the admissions policy of a hypothetical state-funded women's college in Massachusetts, Kellesley, were under review, and this false target error were made, the Court would waste time addressing the issue of whether sex is a good proxy for nurture. It would ask how close the overlap is between the class of women and the class of people who are nurturing. If the policy is of the nonproxy variety, as I believe it is, this inquiry is simply irrelevant. Second, the Court would ask whether admitting nurturing students is an 
important governmental objective. Again this question is extraneous, primarily because this is not what Kellesley is doing.

This brings us to the second flaw with positing a false target: The real and important moral issues non-proxy discrimination raises are ignored. Here, we want to know whether there are good moral reasons for Kellesley to pursue single-sex education. Who benefits, who is hurt, and by how much? What social significance does the action carry? When the Court posits a false target, we miss these questions because we are too busy looking at the relationship between sex and some false target, such as nurturing. Moreover, the inquiry into the legitimacy of the objective does not help because the false target obscures the real objective. We do not want to know whether Kellesley may legitimately seek to admit only nurturing students; we want to know whether it may legitimately admit only women.

When the Court does not posit a false target, it uses a more subtle means to squeeze the non-proxy case into its proxy analysis. Without a target to relate to the classification, the Court compares the reason for classifying to the classification itself. Keeping with the Kellesley College hypothetical, the Court might ask whether the sex discrimination of the admissions policy is substantially related to the goal of providing a supportive educational environment for women. At first blush, this approach looks sensible. Yet it also is misguided and unhelpful, but in a more complex way.

The problem with an analysis that focuses on the relationship between the rationale for the classification and the classification itself is that, although we want to examine both, we do not want to focus exclusively, or even primarily, on their degree of relation. Notice also that this approach alters the concept of relation. In the true proxy cases, we compare the degree of overlap between two sets of people, the set defined by the classification and the set defined by the target trait. Here we examine the degree of relation between a reason for a classification and that classification. It is difficult to grasp what relatedness connotes here. The reasons for a classification must be reasons for employing that classification-in that sense they must be related. But what else? The focus on the degree of fit in each of the Equal Protection doctrine formulations suggests that the Court is interested in whether using the classification is the best, or one of the best, means to achieve the rationale.

This puts the relevant question backwards. To say that something is a reason for adopting a policy is not to say that the policy is the best way of achieving the values or ends embedded in the reason. In fact, the grounding is in the other direction: The reason supports the policy, not the other way around. An example will help to illustrate this point. Suppose I say that I am going to become a doctor and that my reason for 
doing so is that I want to help people. In assessing this choice, we want to know whether the reason is connected to the action, whether doctoring actually does help people. But we do not demand that doctoring be the best or close to the best way of helping people in order to accept helping people as a reason for choosing medicine. If we were analyzing the moral worth of my career choice, we would be interested in the answers to three questions. First, whether helping people is good. Second, whether becoming a doctor will indeed help people. Third, whether there are any other moral concerns to consider, such as whether doctors simultaneously cause other harms.

These three questions are of the non-instrumental variety I identified as relevant for non-proxy discrimination cases. Looking at the Kellesley College example again, we see an analogue for each. Suppose, as I suggested earlier, that Kellesley adopts its women-only admissions policy in order to provide a supportive educational environment for women. In assessing the moral worth of this policy, we are similarly interested in three questions. First, whether providing a supportive educational environment is an important goal. Second, whether a single-sex setting will provide such an environment. Third, whether other moral concerns should be considered, such as harms to those excluded and the social meaning of the policy. Neither of these lists is exhaustive. Rather, by providing a tentative catalogue of the types of moral issues raised by non-proxy cases, I show that the degree of relatedness between the classification and its underlying reason is relatively minor.

In sum, the Court commits a serious mistake in treating the degree of relatedness between the classification and its rationale as the main subject of moral inquiry. First, although the rationale must provide a reason for employing the classification, the classification need not be the best or among the best means of achieving the values embedded in the reason. Second, this conception of the inquiry inverts the relationship between the rationale and the classificatory policy: The rationale is meant to support the policy. Adopting it is not tantamount to asserting that the statute is the best means to achieve the rationale. Third, many other moral questions are more important than the degree of relatedness between the classification and its rationale. Focusing on this degree of connection blinds the Court to these other, more pressing concerns.

\section{B. In Practice}

Having seen how the proxy analysis of Equal Protection doctrine mistreats and misperceives the relevant issues of non-proxy discrimination in hypothetical cases, we will now look at how this doctrinal mistake plays out in actual cases before the Court. 


\section{United States v. Virginia}

We begin with United States $v$. Virginia ${ }^{31}$ because of its evident similarities to the Kellesley College hypothetical discussed above. In this case, we see vividly the harm done by constructing the Equal Protection doctrine as a theory of proxy discrimination. In an effort to conform the question posed by the men-only admissions practices of the Virginia Military Institute (VMI) to the fit analysis mandated by the doctrine, Justice Ginsburg posits a false target and thereby diverts the discussion and analysis onto the wrong questions.

The issue presented in this case is whether Virginia's state-funded military-style college, VMI, may continue to admit only men without violating the Constitutional guarantee of Equal Protection. As the admissions practice employs a sex-based classification, Ginsburg deploys the standard intermediate scrutiny formulation: "The State must show 'at least that the [challenged] classification serves 'important governmental objectives and that the discriminatory means employed' are "substantially related to the achievement of those objectives." 32 For Ginsburg, this test is about fit: There must be a substantial overlap between men (the group defined by the classification) and the group of students legitimately sought. Constitutional infirmity is a matter of overor under-inclusiveness. For Ginsburg, the sex-based classification "must not rely on overbroad generalizations about the different talents, capacities, or preferences of males and females.",33

This standard conception of the wrong that Equal Protection doctrine resists as ill-fit requires that one articulate what class of people or trait of persons the classification only too loosely approximates. Ginsburg must tell us what is the target of the proxy "men" used in the VMI admissions policy. Although Ginsburg discusses two possible targets, one suggested by the State of Virginia in defense of its practice, and one she herself suggests, neither is a sensible reconstruction of the aim of the admissions practice. Because the VMI case presents an instance of non-proxy discrimination, both purported targets mischaracterize the policy's purpose and the important moral questions thereby raised.

The admissions practice of the state-supported Virginia Military Institute raises the following legal and moral question: When, if ever, may the state support single-sex education $?^{34}$ In my view, the sex-based

31. 116 S. Ct. 2264 (1996).

32. Id. at 2275 (quoting Mississippi Univ. for Women v. Hogan, 458 U.S. 718, 724 (1982) (quoting Wengler v. Druggists Mutual Ins. Co., 446 U.S. 142, 150 (1980))).

33. Id.

34. I am aware, of course, of the prudential principle that the Court ought not to address a Constitutional question more broadly than necessary. The question I suggest could be framed in various, narrower ways. For example, whether a state may legitimately support a male-only military 
classification of the admissions policy is not a proxy for anything. VMI admits only men because it seeks an all-male school. Of course, those who determine the VMI policies do so for reasons: There is a rationale for the single-sex choice. But the rationale is not the target of the proxy male. VMI uses the classification "male" in the admissions policy so that only men will be admitted; it seeks no other, overlapping group. VMI thus presents a classic instance of non-proxy discrimination.

As a result, when Ginsburg seeks to articulate the target of the proxy in order to present an ill or adequate fit argument, she has a difficult time. Ginsburg considers two possibilities: sex as a proxy for diversity and sex as a proxy for citizen-soldier, which she takes to be the real target. Both interpretations give an inadequate picture of the relevant legal and moral issues raised by VMI's practice. Ginsburg rejects the first as not the actual target, but in a manner that obscures the relevant moral issues. Worse, that she sees the second as the actual target diverts attention from the pressing question the case poses.

Ginsburg rejects diversity as a sham objective on the basis of illfit. ${ }^{35}$ If diversity were the true goal, she reasons, Virginia would not stop at only one diverse educational option, one all-male military-style college. Rather it would pursue a funding strategy designed to yield a plethora of educational options. ${ }^{36}$ For Ginsburg, the weak fit between this means, keeping VMI all-male, and the end of educational diversity demonstrates what is constitutionally problematic in the policy. While I agree that the lack of fit between the purported means and end may demonstrate that this alleged rationale, diversity, is not the actual reason Virginia had for supporting VMI, ill-fit, by itself, does not make the policy constitutionally problematic. Moreover, the inquiry into fit may demonstrate that diversity is a sham objective, but it may also show that Virginia is simply trying to defend an instance of non-proxy discrimination in the terms required by the proxy doctrine.

college if it also provides support for a leadership course for women at a private women's college. This question, though clearly more narrow than the question I propose in the text, is similar to it in kind and significantly different from the question Ginsburg identifies as raised by these same facts. She sees the VMI question as whether a state-supported military college may use sex as a proxy for citizen-soldier in its admissions praetice. See id. at 2280-82. The question I propose (as well as its narrowing alternatives) treats the classification as an instance of non-proxy sex discrimination.

35. Ginsburg rejects Virginia's assertion that the sex-based classification is used as a means to achieve educational diversity in the state. See id. at 2277,2279 . Before looking at why she rejects this claim, it is important to note that Virginia's assertion exhibits the second conceptual error descrihed above: mistaking the purpose of a classification for its target. As I argue above, the problem with this misconception is two-fold; it overemphasizes fit where fit is of only moderate importance, and it inverts the direction of support between the reason for a policy and the policy itself. If educational diversity is the reason for VMI's admissions practice, mistreating diversity as the target rather than the rationale Ieads to both of the problems identified in theory.

36. See id. at 2267. 
This focus on the degree of fit between the rationale for the policy, educational diversity, and the policy, single-sex education at VMI, obscures a more central issue. The problem with the VMI policy is not that Virginia could pursue its diversity goal more efficiently, but rather that its chosen way of pursuing that goal works an unfairness to women. Clearly, determinimg what fairness requires in terms of state-supported educational opportunities is a difficult question, yet that is the question the Court should address.

In order to see that the fixation on fit is a diversion, suppose that Virginia supported more diversity. In addition to VMI, suppose a hypothetical Virginia also provides financial support to an all-male nursing school, an all-male business school, and an all-male cooking school. Ginsburg claims that the fit between the classification and the diversity objective is not tight enough on the VMI facts because the state has chosen an extremely inefficient means of achieving its goal. In terms of efficiency, the hypothetical Virginia is an improvement-there is more educational diversity. There is a tighter fit between classification and objective and therefore less of a constitutional Equal Protection problem. This conclusion, however, clearly clashes with our intuitions. In fact, the hypothetical state presents more of a constitutional problem, works more unfairness to its daughters, and offers less Equal Protection.

After rejecting diversity as the objective of the VMI policy, Ginsburg interprets the policy as an instance of proxy discrimination in which sex is a surrogate for persons who would make good citizensoldiers. Like the law firm that uses grades as a proxy for legal ability, VMI, under Ginsburg's interpretation, is using sex as a stand-in for the elusive qualities that will inake an applicant a good citizen-soldier.

Described in this manner, VMI's policy of excluding woinen clearly violates the Equal Protection Clause. Intermediate scrutiny requires that the classification (male) be substantially related to the target (citizen-soldier material). But because many women will be able to meet the physical, emotional, and intellectual requirements of the VMI course and consequently will graduate as laudable citizen-soldiers, there will be a significant number of false negatives. This under-inclusiveness of the category (male) is the constitutional problein for the Court: "[T] he question is whether the State can constitutionally deny to women who have the will and capacity, the training and attendant opportunities that VMI uniquely affords." ${ }^{37}$ To this question, the Court answers no.

The Court's conception of the constitutional problem as one of illfit between the proxy and the target dictates its sense of the appropriate remedy. It is the false negatives-women who would make good citizensoldiers-whose right to Equal Protection has been violated.

37. Id. at 2280 . 
Consequently, "it is for them that a remedy must be crafted, a remedy that will end their exclusion from a state-supplied educational opportunity for which they are fit ...."38 On this basis, the Court rejects the Virginia Women's Institute for Leadership (VWIL) program set up and funded by the state as an adequate remedy. For the women with the ability and inclination to attend VMI, the offer of a funded leadership program with a different methodology, as well as lesser status, facilities, and endowment, is no remedy at all.

The Court attempts to leave open the question whether any statesupported school may segregate by sex. ${ }^{39}$ But the logic of an analysis in which any under-inclusiveness of the gender classification creates a constitutional problem would seem to close that door.$^{40}$ If the use of sex as an admissions criterion is always viewed as a proxy for some other skill or ability (following the Court's conception of discrimination as proxy discrimination), it is likely that there will always be some woman (or man, if men are the sex excluded) who has the desired trait. Real differences may separate men from women, but the sexes are not so dissimilar that all individuals of one sex will lack a trait or quality generally found in the other. This is an improper test for determining when, if ever, statesupported single-sex education is permissible. Some women will surely thrive at VMI and make excellent citizen-soldiers. These women are thus denied the opportunity to do something of which they are capable. But capability does not imply entitlement. In order to know whether these women are entitled to attend VMI, we need a theory of fair classification. The fact that some women would succeed at VMI initiates the need for such a theory to be applied in this case; it does not itself provide that analysis.

On what, then, should the determination turn? In my view, the relevant questions are non-instrumental in nature and call for a direct examination of the effects of the policy in question. Here the Court should examine whether excluding women from the opportunity VMI offers deprives female Virginians of their fair share of the state's education dollars and whether the social significance of supporting an all-male military academy based on adversative methodology reinforces stereotypes which will ultimately limit women's opportunities.

38. Id. at 2284 .

39. See id. at 2276 n.7.

40. Interestingly, the tone of the opinion suggests that any under-inclusiveness would damn the classification; so long as there is at least one woman who can make the grade, VMI has a problem. For example, the Court asserts that "the State's great goal is not substantially advanced by women's categorical exclusion, in total disregard of their individual merit, from the State's premier 'citizensoldier' corps." Id. at 2282 (suggesting that even one individual with the relevant merit would create a constitutional problem for the VMI admissions policy). But a standard that requircd no underinclusiveness between classification and target is surely a stricter standard of review than intermediate scrutiny would suggest. 
The inquiry that the Court of Appeals endorses and Ginsburg explicitly rejects, ${ }^{41}$ regarding the "substantive comparability" of VMI and the VWIL program, is probably relevant. If Virginia supported a wellrespected, unique school open only to women (though not military in nature and with different educational goals than VMD, this would affect whether Virginia's support of VMI violated the Equal Protection Clause. I do not mean to suggest that substantive comparability is dispositive, only that it is relevant. Ginsburg herself intermittently endorses this view, while at the same time explicitly rejecting the "substantive comparability" analysis of the Court of Appeals. For example, she rebuffs Virginia's suggestion that VWIL provides an adequate remedy for the constitutional violation on the grounds that that program is a "pale shadow' of VMI in terms of the range of curricular choices and faculty

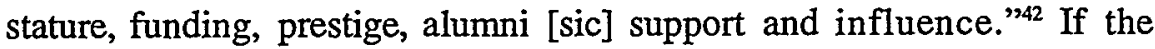
appropriateness of the remedy were simply a matter of assuring that those women who meet the non-sex-based admissions criteria of VMI and want to attend are admitted, the fact that VWL is a "pale shadow" of VMI would be irrelevant. This only becomes relevant if a respected but different women's school could vitiate the Equal Protection challenge. Like the Court of Appeals, and like Ginsburg intermittently, I believe this would matter.

In sum, the conception of discrimination as proxy discrimination, which is embedded in contemporary Equal Protection doctrine, constrains the Court's analysis in United States v. Virginia. Because that doctrine has proxy discrimination as its implicit subject, the tests employed and issues that become salient are relevant for instances of proxy discrimination only. As a result, the Court must manufacture a proxy and a target for this instance of non-proxy sex discrimmation in order to plug its facts into the conceptual apparatus available. The Court's positing of the citizen-soldier as this false target leads to an inappropriate emphasis on fit-whether women have the skills and abilities to succeed at VMI. In a footnote, Ginsburg asserts that the opinion does not condemn all state-supported single-sex education. ${ }^{43}$ Instead she identifies the uniqueness of VMI's program as the dispositive feature. ${ }^{44}$ In this footnote, she begins the difficult but necessary task of articulating the considerations relevant to answering the question the case really poses: When, if ever, may the state support sex-segregated educational programs? The uniqueness of VMI's program is irrelevant to the analysis

\footnotetext{
41. See id. at $2282-83$.

42. Id. at 2285 .

43. See id. at 2276 n.7.

44. See id.
} 
she employs in the text, but central to the non-proxy based inquiry I advocate. This analysis should be moved from footnote to text.

\section{Romer v. Evans}

The amendment to Colorado's Constitution at issue in Romer $v$. $E_{\text {vans }}{ }^{45}$ also presents an example of non-proxy discrimination erroneously analyzed as proxy discrimination. In Romer, the Court held unconstitutional, under a rational-basis standard, Amendment 2 to Colorado's Constitution. Amendment 2 prohibits state and local legislative, judicial, and executive branches of government from affording protection to gays and lesbians against discrimination on the basis of sexual orientation or conduct. ${ }^{46}$ This Amendment thus forbids antidiscrimination protection on the basis of being or acting gay.

Amendment 2 draws a distinction between discrimination on the basis of sexual orientation and other forms of discrimination, such as by race, sex, and age. Colorado thus denies gays and lesbians the opportunity for protective laws against discrimination on the basis of this defining trait. There is surely no proxy discrimination at work: "[H]omosexual, lesbian or bisexual orientation, conduct, practices or relationships"47 may not entitle the person to antidiscrimination protection. Although the Amendment forbids a type of antidiscrimination protection, it also selects a set of people. Gays and lesbians, defined by either orientation or practice, are not entitled to a certain type of legal protection. No one could seriously believe that the law identifies gays and lesbians in order to reach a different target group, as use of this classification as a proxy would envision. Romer's Amendment 2 is an especially clear example of non-proxy discrimination.

The Court's treatment of this case actually acknowledges the inaptness of current Equal Protection doctrine to handle the issue presented here: "Amendment 2 confounds this normal process of judicial review." 48 Justice Kennedy, for the Court, neither attempts to identify a target for the classification nor discusses the issues of fit, over- and under-inclusiveness, required to determine if the classification is

45. 116 S. Ct. 1620 (1996).

46. Amendment 2 reads:

No Protected Status Based on Homosexual, Lesbian, or Bisexual Orientation. Neither the State of Colorado, through any of its branches or departments, nor any of its agencies, political subdivisions, municipalities or school districts, shall enact, adopt or enforce any statute, regulation, ordinance or policy whereby homosexual, lesbian or bisexual orientation, conduct, practices or relationships shall constitute or otherwise be the basis of or entitle any person or class of persons to have or claim any minority status, quota preferences, protected status or claim of discrimination.

Id. at 1623 (quoting CoLo. CoNsr. art. $11, \S 30 \mathrm{~b}$ ).

47. Id.

48. Id. at 1628 . 
rationally related to a legitinate governmental objective. Since the target of the classification is the same as the proxy, Kennedy is limited to stating the Amendment is "at once too narrow and too broad" in that "it identifies persons by a single trait and then denies them protection across the board. $" 49$ In acknowledging that the Amendment directly identifies a class of persons so as to deny them broad protections, he explicitly admits that the Amendment reaches exactly those persons it seeks to reach. The Amendment targets gays and lesbians in order to reach them. This is clearly non-proxy discrimination.

Kennedy's opinion is largely devoted to examining whether the objective of the statute is legitimate. In this sense, the Court's opinion is similar to a proper non-proxy based analysis. Remember that in proxybased Equal Protection doctrine, the Court looks primarily at the fit between the proxy and the target and secondarily at the legitimacy of the target. In non-proxy analysis, attention would instead focus exclusively on whether classifying in the manner the law dictates is permissible-the non-instrumental issues such classification entails. To the extent that concentrating on the legitimacy of the objective becomes an inquiry into these questions, Romer's treatment of Amendment 2 would not be substantially misguided.

However, the Court's Equal Protection doctrine blocks full examination of the relevant issues..$^{50}$ As Kennedy rightly explains, Amendment 2 is "a classification of persons undertaken for its own sake"st-the classification is not used in order to reach a different class of persons. Rather, it is used to classify precisely in the manner it dictates. For Kennedy, such quintessential non-proxy classification is "something the Equal Protection Clause does not permit." If this is unequivocally so, if all non-proxy-based classification is clearly prohibited by the Equal Protection Clause, then Kennedy need not examine any particulars about this classificatory scheine in order to determine that it is impermissible.

However, Kennedy does examine some of the issues that should be viewed as relevant to determining whether this instance of non-proxy based discrimination is permissible, but he does not adequately develop them. For example, Kennedy sees Amendment 2 as an instantiation of "animus" toward homosexuals. If the classification is ineant to enact

49. Id.

50. As I will argue in more detail below, the reason the Court lacks a theory adequate to distinguishing permissible from impermissible non-proxy discrimination is because all non-proxy discrimination has come to be seen as wrong. If all non-proxy discrimination is wrong, the only theory one would need would be a theory for proxy cases - one up to the task of distinguishing benign from pernicious uses of classifications as proxies.

51. Id. at 1629.

52. Id. 
and enforce the view that gays are less worthy of respect as persons, this is a reason to strike it down. Justice Scalia, in dissent, sees the law as the expression of legitimate disapproval for homosexuality. Distinguishing legitimate disapprobation from illegitimate animus is a task the opinion should undertake. Because the Court sees all non-proxy discrimination as clearly impermissible and therefore lacks a theory geared to this task, this important issue is largely left unanalyzed. The only theory the Court does have is one built to distinguish permissible from impermissible proxy discrimination, a theory that is completely unhelpful in this case.

\section{IV}

\section{The ORIGIN OF THE MisconcePtion}

\section{A. The Original Evil: De Jure Racial Discrimination}

Ironically, it is because the Equal Protection Clause was grounded originally in wrongful non-proxy discrimination that its current doctrinal regime is designed to deal only with proxy cases. In the beginning, after passage of the Fourteenth Amendment, the Equal Protection Clause was infrequently used to strike down state laws. A few prominent cases stand out, which we will examine below. But it was not until the era of the $1950 \mathrm{~s}$ and $60 \mathrm{~s}$ that the Clause came to have a distinct resonance. With Brown v. Board of Education ${ }^{53}$ and the cases which followed dismantling de jure racial segregation, wrongful discrimination became synonymous with racial segregation. ${ }^{54}$ These cases are instances of nonproxy discrimination-racial segregation as its own end. While some of these cases offer reasons why a particular statute's non-proxy discrimination violates the Equal Protection Clause, these reasons never coalesced into a theory of when non-proxy discrimination is wrong. Instead, the lesson of these cases was that all non-proxy discrimination is wrong. The instance of non-proxy discrimination was fused with the type of discrimination itself. As a result, the Court never developed a theory to distinguish wrongful from permissible non-proxy discriminatiou because it simply did not see the latter as a conceptual possibility.

In the early days, when the Equal Protection Clause was used successfully to strike down a state statute, the statute usually presented an instance of straightforward non-proxy racial discrimination. The 1880 case of Strauder $v$. West Virginia ${ }^{55}$ provides a good example. In Strauder, the Court allowed a black defendant to remove his case to

53. 347 U.S. 483 (1954).

54. See, e.g., Koppelman, supra note 1, at 13 ("The evil that antidiscrimination law seeks to remedy is most typically understood by analogy with or as instantiated by the segregated school that the Supreme Court declared unconstitutional in Brown v. Board of Education.").

55. 100 U.S. $303(1880)$. 
federal court because West Virginia law permitted only whites to serves as jurors. This statute constituted non-proxy discrimination because the sorting by race that the statute effectuated was itself the purpose of the statute. In Strauder, the Court struck down the West Virgiuia law because it was non-proxy discrimination that disadvantaged blacks. In the Court's words, the Equal Protection Clause grants blacks "the right to exemption from unfriendly legislation against them distinctly as colored." $" 56$

Plessy v. Ferguson ${ }^{57}$ presents the other side of the Court's early and inchoate theory of non-proxy discrimination. Louisiana law provided that intrastate railways, street cars, and other modes of transport must segregate the passenger seating compartinents by race. The statute's purpose was clearly to effect the racial segregation indicated by the classification. As the statute constituted non-proxy racial discrimination, the Court acknowledged that it raised an Equal Protection issue. ${ }^{58}$ However, the facts lacked disadvantage, the unfriendliness of which the Strauder Court spoke. In a now infamous passage, Justice Brown, for the Court, asserts that if "the enforced separation of the two races stamps the colored race with a badge of inferiority ... it is not by reason of anything found in the act, but solely because the colored race chooses to put that construction upon it." 59 Of course, one can easily critique Plessy's blindness to the social meaning of segregation at that time. But more important for our purposes, both Plessy and Strauder see the Equal Protection Clause as addressing non-proxy racial classification.

As the doctrine of Equal Protection developed, the Court also began to see Equal Protection issues in proxy discrimination. Thus, it needed a conceptual scheme for such cases. The early development of such a doctrine can be found in Korematsu $v$. United States. ${ }^{60}$ In Korematsu, the Court upheld the constitutionality of military orders excluding persons of Japanese ancestry from the West Coast. As the Court viewed these ordinances, their purpose was not to treat JapaneseAmericans differently for the sake of treating them differently-nonproxy discrimination-which clearly would have been impermissible. Rather, the Court found that the purpose was to target disloyal citizens or residents and that the classification Japanese-American was a proxy for that target.

In order to make sense of the military rationale for the policy, the Court needed a theory of proxy discrimination distinct from the

56. Id. at 308 (emphasis added).

57. 163 U.S. 537 (1896).

58. In the Court's view, so long as the regulation in question was "reasonable," it would not run afoul of the Fourteenth Amendment. See id. at 550.

59. Id. at 551 .

60. 323 U.S. 214 (1944). 
disadvantaging for its own sake clearly proscribed in Strauder ${ }^{61}$ It held that if the target of the racial proxy, isolating disloyal residents, is itself legitimate, then as long as a "definite and close relationship"62 between the proxy and the target exists, even a racial proxy may be permissible, though the use of a racial classification is "immediately suspect."

Thus, before Brown v. Board of Education, ${ }^{64}$ the Court employed two theories, one for non-proxy cases like Strauder and Plessy, and one for proxy cases like Korematsu. If a statute was non-proxy in form, the Court struck it down if it disadvantaged the race it classified. This was the rule of Strauder and Plessy. In proxy cases, the Court employed a two-part test easily recognizable as the fit theory of current doctrine. The target of the racial proxy must be legitimate, and the relationship between proxy and target must be close.

During the era of Brown, the Court gradually repudiated de jure racial segregation in a series of settings. ${ }^{65}$ This marked the solidification of non-proxy racial classification as the basic and paradigmatic evil proscribed by the Equal Protection Clause. The use of racial classification is impermissible when the racial minority is explicitly disadvantaged and when the classification's purpose is segregation. Brown assimilates this second subtype of non-proxy discrimination, segregation, to the first subtype, explicit disadvantaging, in order to justify striking it down. The segregating legislation harms and disadvantages black school children by "generat[ing] a feeling of inferiority as to their status in the community that may affect their hearts and minds in a way unlikely ever to be undone." ${ }^{166}$ The Brown opinion also suggests, but does not explicitly adopt, a fledgling theory that might have developed into an account of wrongful non-proxy discrimination. De jure racial segregation is wrong because of the meaning of this practice in our society at that time. In other words, it is wrong contingently, not "inherently."

The Court further developed this moral concern with the social meaning of a classificatory practice in the 1964 case of Anderson v. Martin. ${ }^{68}$ There it struck down a Louisiana statute that required all

61. As Justice Black explains, "racial antagonism never can justify the existence of ... restrictions" that "curtail the civil rights of a single racial group." Id. at 216.

62. Id. at 218 .

63. Id. at 216 .

64. 347 U.S. 483 (1954).

65. In 1955, the Court affirmed decisions desegregating public beaches, see Mayor of Baltimore v. Dawson, 350 U.S. 877 (1955), and public golf courses, see Holmes v. Atlanta, 350 U.S. 879 (1955). In 1956, the Court affirmed a decision desegregating public buses, see Gayle v. Browder, 352 U.S. 903 (1956), and in 1958, another decision desegregating public parks, see New Orleans City Park Improvement Ass'n. v. Detiege, 358 U.S. 54 (1958).

66. Brown, 347 U.S. at 494.

67. See id. at 495.

68. 375 U.S. 399 (1964). 
election nominating papers and ballots to designate the race of each candidate. In rejecting Louisiana's argument that the statute was constitutional because it evenhandedly required both white and black candidates to designate race on the election materials, the Court relied on the social significance and effect of this requirement. According to the Court, "by directing the citizen's attention to ... race ..., the State indicates that [race] is ... important-perhaps paramount,"- " $[t]$ he vice lies not in the resulting injury but in the placing of the power of the State behind a racial classification that induces racial prejudice at the polls. ${ }^{\circ 69}$

I emphasize this concern because the discussion in Anderson looks like the beginnings of a theory of wrongful non-proxy discrimination that I argue for here. Rather than speaking about the fit between some proxy and its target, the Anderson Court correctly recognizes the Louisiana statute as an instance of non-proxy discrimination. In so doing, the Anderson Court addresses the type of issue important to assessing the moral permissibility of instances of non-proxy discrimination, the social meaning expressed by the practice.

Unfortunately, the Court did not pursue the development of an account of wrongful non-proxy discrimination. Instead, in Loving $v$. Virginia ${ }^{70}$ decided only three years after Anderson, the Court treats all non-proxy discrimination as wrong, thereby dispensing with the need for a theory that would distinguish between permissible and impermissible instances. In Loving, the Court struck down Virginia's antimiscegenation statute, reasoning that racial classifications will only be upheld if "necessary to the accomplishment of some permissible state objective, independent of the racial discrimination which it was the object of the Fourteenth Amendment to eliminate."11 The Loving opinion lacks explanation or justification of this exclusion. The Court begins with the premise that "invidious racial discrimination" will not be tolerated $^{72}$ but offers little analysis or assistance to the reader in understanding when classifications are invidious. Instead, the Court tells us only that racial classifications must "be subjected to the 'most rigid scrutiny" "73 and struck down where they amount to discrimination for its own sake, what I have been calling non-proxy discrimination.

While there have been murmurings of a theory of wrongful nonproxy discrimination, they have not inatured. Instead, the conception of non-proxy discrimination as paradigmatic wrongful discrimination

69. Id. at 402 .

70. 388 U.S. 1 (1967).

71. Id. at 11 (emphasis added).

72. Id. at 10 ("The clear and central purpose of the Fourteenth Amendment was to eliminate all official state sources of invidious racial discrimination in the States.").

73. Id. at 11 (quoting Korematsu v. United States, 323 U.S. 214, 216 (1944)). 
solidified, stymieing the growth of a wrongful non-proxy discrimination theory. Had the Court in Loving provided reasons, this project may have advanced. Giving reasons would have helped delineate wrongful from permissible non-proxy discrimination.

In the period following, roughly the 1970 s to the present, we see the solidification and acceptance of the notion that all non-proxy discrimination is clearly wrong. For example, in University of California Regents v. Bakke, ${ }^{74}$ Justice Powell dismisses without consideration or discussion the university's defense of its affirmative action policy as a way to ensure that there are more black doctors. According to Powell,

If petitioner's purpose is to assure within its student body some specified percentage of a particular group merely because of its race or ethnic origin, such a preferential purpose must be rejected not as insubstantial but as facially invalid. Preferring members of any one group for no reason other than race or ethnic origin is discrimination for its own sake. This the Constitution forbids. ${ }^{75}$

To support his view that discrimination for its own sake is clearly forbidden, Powell cites Loving, McLaughlin v. Florida, ${ }^{76}$ and Brown. The rejection of non-proxy racial discrimination, which, at least in the case of Brown, is justified in terms of the social meaning of the practice of segregation and in terms of the harm thereby caused, is transformed and solidified into a rejection of all non-proxy racial discrimination. Consequently, by the time of Bakke in 1978, no analysis of these moral concerns is required.

This brings us to the present. Although there are two types of discrimination, a well-developed doctrine for the non-proxy branch is missing. Due to the unfortunate conflation of pernicious non-proxy discrimination with all non-proxy discrimination, the Court never found the need to develop a theory to distinguish permissible from impermissible types. The Court employs a robust, if at times confused and complicated, account of when proxy discrimination violates the Equal Protection Clause yet gives no comparable theory for non-proxy cases. Because it sees non-proxy discrimination as paradigmatically evil, the Court has no way to analyze the instances of non-proxy discrimination that are morally ambiguous. State-funded single-sex education and affirmative action are two clear examples. A full Equal Protection doctrine, like a complete moral theory of wrongful discrimination, should include two branches, an account of wrongful proxy discrimination and

74. 438 U.S. 265 (1978).

75. Id. at 307.

76. 379 U.S. 184 (1964) (striking down a Florida law that forbade cohabitation by a man and woman of different races). 
an account of wrongful non-proxy discrimination. At present, this second branch is missing.

\section{B. Tussman and tenBroek}

The Court's conception of discrimination as proxy discrimination and of wrongful discrimination as ill-fit between proxy and target also owes much to the influential article of Joseph Tussman and Jacobus tenBroek, The Equal Protection of the Laws, ${ }^{77}$ published in 1949, the eve of the heyday of the Equal Protection Clause. The Tussman and tenBroek article, which ranks among the top 20 law review articles in number of times cited, ${ }^{78}$ articulates a conception of the Equal Protection Clause and the harm it is intended to proscribe which largely became the standard conception of the Clause and its motivating principle. That is not to say that it was universally accepted, but that it was the measure used to compare competing views.

Tussman and tenBroek begin their piece with a paradox. In order to achieve myriad aims, laws must employ classifications. Yet, as they saw it, the Equal Protection Clause required that all persons be treated equally, which, at least at first blush, would seem to mean the same. ${ }^{79}$ But if laws that divide and classify people necessarily treat these people differently, do they necessarily violate the Equal Protection guarantee? Since the answer cannot be yes, Tussman and tenBroek seek an alternative understanding of the Clause. The Rule of Law ideal provides it. In order to treat people equally, one need not treat them the same. Rather, all Equal Protection requires is that likes be treated alike, and differents differently. ${ }^{80}$ As Tussman and tenBroek characterize it, the Equal Protection Clause embodies a principle of "reasonable classification."

The likeness between people affected by a statute must come from some source other than the distinction defined by the statute at issue. Tussman and tenBroek correctly reject a conception of "natural classes": people are not just naturally like some other people and

77. Joseph Tussman \& Jacobus tenBroek, The Equal Protection of the Laws, 37 CALIF. L. REv. 341 (1949).

78. See Fred R. Shapiro, The Most-Cited Law Review Articles Revisited, 71 CHI.-Kent L. REv. 751,766 (1996) (ranking the Tussman and tenBroek article as the fourteenth most-cited law review article of all time). But see James E. Krier \& Stewart J. Schwab, The Cathedral at Twenty-Five: Citations and Impressions, 106 YALE L.J. 2121, 2139 (1997) (critiquing Shapiro's method of calculating the real influence of scholarly work and suggesting a substitute). On the Krier and Stewart list, Tussman and tenBroek fall to number 103. While this is significantly lower, it still suggests sustained and substantial influence.

79. See Tussman \& tenBroek, supra note 77, at 344.

80. See id.

81. See id. 
naturally different from others. ${ }^{82}$ They are both similar and dissimilar in infinite ways. ${ }^{83}$ According to Tussman and tenBroek, the purpose of the statute defines the relevant similarities. Given the purpose of the statute, are like people treated alike? ${ }^{84}$

At this point in their theory, Tussman and tenBroek commit the error that leads them to devise a theory for proxy-discrimination cases only, without feeling a conceptual strain from non-proxy cases. Tussman and tenBroek conceive of a legislative purpose as doing something good or preventing something bad. This description of purpose then gets inexplicably transformed into the identification of persons with "good-making" or "mischief-making" properties. By this seemingly innocuous step, Tussman and tenBroek redescribe all legislative purposes as attempts to select certain people. But clearly not all conceivable legislative purposes are about trying to target certain people. In fact, only classificatory laws that discriminate by proxy are of this type.

Another way to describe the slippage in Tussman and tenBroek's argument is as a conflation of the target and the purpose. In proxy cases, the law uses a classification which identifies one set of persons as a proxy for persons with a different trait (the good-making or mischief-making property, in Tussman and tenBroek's vocabulary). In proxy cases, the purpose of the statute is the reason for seeking the target. Because this is so, Tussman and tenBroek can say plausibly that judging whether relevant equalities have been maintained in Equal Protection cases is about judging the fit between the proxy class and the target class and describing this as judging the relationship between the classification and the legislative purpose. But in those cases where the classification does not aim at a target, where the purpose relates instead to the named classification itself, there are not two sets of persons whose overlap can be judged. Basically, Tussman and tenBroek miss this: They overlook the non-proxy form of classification because they conflate the target of the proxy with the law's purpose. In doing so, they inaptly

82. See id. at 346. There were, in the Clause's infancy, some mistakes in grasping what this principle requires, according to Tussman and tenBroek. A classificatory law distinguishes betwcen two sets of people (or things). If the distinction between these sets created by the law itself is enough to satisfy the requirement of reasonable classification, the Clause becomes empty. Tussman and tenBroek describe this as the mistake made by the first Justice Harlan in a case dealing with restrictions on makers of margarine. Harlan upheld the restrictions on the grounds that all makers of margarine were being treated equally. See id. at 345 (discussing Powell v. Pennsylvania, 127 U.S. 678,687 (1888)). According to Harlan's rationale, as Tussman and tenBroek explain, "a law applying [only] to red-haired makers of margarine would [also] satisfy the requirements of equality," since all red-haired margarine makers would be treated equally under the law. Id.

83. See Scott Brewer, Exemplary Reasoning: Semantics, Pragmatics, and the Rational Force of Legal Argument by Analogy, 109 HARv. L. REv. 923, 932 \& n.19 (1996).

84. See Tussman \& tenBroek, supra note 77, at 345. 
characterize all classificatory laws as proxy discrimination and consequently characterize the Equal Protection inquiry as an issue of fit.

The Venn diagrams that Tussman and tenBroek use to explain their conception of wrongful discrimination as ill-fit, as well as the Equal Protection theory this approach embodies, became standard in the years that followed publication of the Tussman and tenBroek article. Consistently ranked among the top twenty law review articles cited by colleagues, Tussman and tenBroek's focus on classificatory precision reinforced this developing tendency in the doctrine. For example, twenty years after publication, Gerald Gunther, in his 1969 article Equal Protection, ${ }^{85}$ treats Tussman and tenBroek as the reigning conceptual schema in relation to which Gunther will analyze then current developments in Equal Protection doctrine. Another twenty years later, the influence continues: In 1989, Kenneth Simons offers a challenge to Tussman and tenBroek, who, according to Simons, "have exerted a remarkably strong imfluence on legal reasoning." ${ }^{186}$ Finally, Owen Fiss identifies Tussman and tenBroek's conception of "means-ends rationality" as "the core idea--the foundational concept-of the antidiscrimination principle." ${ }^{.87}$

\section{Smoking Out Invidious Purposes}

The above two mutually reinforcing accounts describe how Equal Protection doctrine came to ignore the moral and legal problems presented by non-proxy discrimination. They present this development as a mistake, a misapprehension, understandable yet misguided. But the dominance of fit in current Equal Protection doctrine may also serve a purpose. As John Hart Ely explains, the function of heightened scrutiny and "in particular its demand for an essentially perfect fit, turns out to be a way of 'flushing out' unconstitutional motivation." ${ }^{88}$ So, perusing the argument of this Essay, a reader might be tempted to think I have simply missed the point of current doctrine. The rationale for the fit analysis, one might argue, is instrumental: Policing for tight fit when suspect classifications are employed helps to smoke out illegitimate motives.

85. See Note, Equal Protection, 82 Harv. L. Rev. 1065 (1969).

86. Kenneth W. Simons, Overinclusion and Underinclusion: A New Model, 36 UCLA L. REv. 447,450 (1989).

87. Owen M. Fiss, Groups and the Equal Protection Clause, in Equality and Preferential TREatment 88 (Marshall Cohen et al. eds., 1977); see also JoHN E. NowaK \& Ronald D. RotUNDa, Constitutional LAw (4th ed. 1991). In the section entitled Government Classifications and the Concept of Equal Protection, Nowak and Rotunda characterize the issue of Equal Protection as an issue of fit between a classification and a legitimate governmental objective. Both the text and the footnotes cite the Tussman and tenBroek article several times. It is notably the only source relied on for an explanation of the underlying conception of Equal Protection. See id. at 570-73.

88. John Hart Ely, Democracy and Distrust 146 (1980). 
Ely presents this explanation in the course of describing the virtues of the fit doctrine. ${ }^{89}$ Because it is hard to know for sure why a legislative body actually enacts a classificatory policy, perhaps benign reasons will be offered when the law really is enacted with invidious intent. ${ }^{90}$ Current doctrine will help to reveal this after-the-fact legitimation because "where the real goal was unconstitutional, the goal that fits the classification best will not be invocable in its defense, and the classification will have to be defended in terns of others to which it relates more tenuously." 11

This defense of current doctrine has some merit. Fit can help to reveal subterfuge. But it is not a panacea. Moreover, the dominance of fit-based analysis blinds us to important differences between types of classification cases and to the possibility that some intentional discrimination may be permissible. To see these limitations, we must take a closer look at the kinds of cases this "smoking out" theory envisions. They are of two types. In the terms put forward in this Essay, they include a) proxy cases in which a benign target is substituted for a pernicious one; and b) non-proxy cases masquerading as proxy cases.

In the first of these types, the fit analysis is helpful and appropriate. For example, fit helps the Court in Skinner v. Oklahoma ${ }^{92}$ to see that the statute's real purpose is to prevent lower-class criminals from reproducing. While a eugenic purpose of preventing the birth of future criminals (on the assumption that propensity to commit crimes is heritable) may be permissible, the goal of eradicating only poor criminals is not. This real goal is revealed by the under-inclusiveness of the classification in relation to the stated purpose of preventing criminals from reproducing. Because the habitual embezzler is not also subject to sterilization, the class-based aim of the statute is made manifest. ${ }^{93}$

In proxy cases like Skinner, fit analysis can help to uncover a fabricated target. As I agree that fit doctrine is sensible for proxy cases, what this understanding of the doctrine provides is a gloss on why ill-fit is morally problematic in cases of classification by proxy.

The other area in which fit-based analysis can smoke out illegitimate motives is the non-proxy case masquerading as a proxy case. For example, suppose a state's district attorney refuses to hire any women lawyers for his staff. The DA claims that although he has nothing

89. See id. at $145-70$.

90. Cases and commentary notably fail to elaborate on what makes an intent invidious. At times, it seems that the intent to classify on the basis of race for its own sake (non-proxy race discrimination) is always such. Part VI of this Essay, by articulating a view of when non-proxy discrimination is wrong, attempts to remedy this gap.

91. Ely, supra note 88 , at 146.

92. 316 U.S. 535 (1942).

93. See id. at 541 . 
against women, he wants aggressive lawyers and women on average are simply less aggressive than men. What the fit analysis promises to provide is a way to see that this asserted goal (aggressive lawyers) may be a mere cover for the clearly illegitimate desire not to hire women lawyers. Since sex will not be correlated closely enough with aggressiveness, the policy will fail. The virtue, according to Ely, of attacking the policy on fit grounds rather than on the basis of improper purpose, is that it allows the court to criticize the means employed rather than the legislative goals themselves. ${ }^{94}$

Treating this case with the fit-based doctrine does no harm, because if it is really a non-proxy case-i.e., if the articulated purpose is a sham-it would also fail to be morally permissible..$^{95}$ Something may be lost in not seemg the real reasons why such an instance of non-proxy discrimination is forbidden, but something is gained in not having to challenge the articulated purpose.

However, applying the fit-based approach pervasively will cause harm that ultimately outweighs the benefits gained by obviating the need to discern and challenge legislative motivation. It is the arguably permissible non-proxy cases that are mistreated. The dominance of fit deprives us and the Court of the opportunity to analyze, understand and debate the real moral issues embedded in these non-proxy cases. For example, state-supported single-sex education would probably fail on fit grounds in all contexts. The class of women is unlikely to be homogeneous enough or different enough in the aggregate from the class of men to correlate closely enough with any purported target of such a classification. The fate of the citizen-soldier target posited by Justice Ginsburg in United States $v$. Virginia is paradigmatic.

If non-proxy cases are morally different and therefore require a distinct legal analysis to assess whether they violate the Equal Protection Clause, then the attempt to posit targets for the classifications and to force these policies into a fit-based schema will damage our understanding of what this Clause protects and cramp the ability of our policy-makers to experiment with social forms. Furthermore, the dominion of fit will itself engeuder subterfuge. Because current doctrine looks for a fit between the classification employed and some target class, state actors and the lawyers defending them will be forced to artful contrivance to come up with a purported target of the non-proxy based classifications employed.

One last note on this instrumental defense of the fit doctrine. One of this Essay's themes has been that non-proxy discrimination is

94. See ELY, supra note 88, at 146.

95. For an account of the right theory, in my view, to apply to non-proxy cases, see Part V1 infra. 
sometimes permissible. The way that the Equal Protection Clause has developed has blinded us to this possibility by conflating wrongful nonproxy discrimination with all non-proxy discrimination. As a result, we have one doctrine-fit - on the assumption that it is only in proxy cases that we must distinguish between permissible and impermissible classification. Clinging to current doctrine will perpetuate this blindness.

Consider the well-known hypothetical suggested by Paul Brest and discussed by Ely ${ }^{96}$ of the high school primcipal who seats black children on one side of the stage in the school's auditorium and white children on the other because he likes the aesthetic effect thereby created. In discussing this example, Ely concedes that there is no fit issue ${ }^{97}$-in my terms this is because it is a non-proxy case. But, he insists, the doctrine's second requirement, that the state's goal have "some degree of substantiality"98 also helps in ferreting out pretextual purposes. Of the Brest hypothetical Ely concludes, "the goal is so trivial in context that you have to believe it's a rationalization for a racially motivated choice." 99 But this is not an answer to the constitutional question; it merely restates the issue the case presents. The principal's intention, explicitly acknowledged, is to classify by race. Of course, the choice is racially motivated if this means that the principal so classifies in order to reach precisely the people thereby reached. In other words "racially motivated" may be synonymous with non-proxy in form. Because Ely stops here, he does not reach the question actually posed by the hypothetical: Can a school principal make such a "racially motivated" choice? To answer this question, we need a deeper analysis, one that will look at the moral issues non-proxy discrimination raises.

\section{$\mathrm{V}$ \\ ECHOES OF OTHER CRITIQUES}

There is, of course, nothing new under the sun. That being so, one would expect to find overlap between what I argue in this Essay and what has been claimed by others before. And there is. Below, I sketch some of that overlap in order first to acknowledge my debt to others and second to explain and clarify the ways in which what $I$ have argued differs from and shares the insights and commitments of others who write and think about discrimination.

96. See Paul Brest, Processes of Constitutional Decision-Making 489 (1975); Ely, supra note 88 , at 148.

97. See ELY, supra note 88, at 148.

98. Id. at 147 .

99. Id. at 148. 


\section{A. Fiss}

Owen Fiss believes that the Equal Protection Clause is best seen as animated by an anti-caste principle: a protection for disadvantaged social groups from structured subordination. His influential article, Groups and the Equal Protection Clause, ${ }^{100}$ articulates a view of Equal Protection that is broader and more far-reaching than my own, but which shares with this Essay two basic claims. First, "current" Eqnal Protection doctrine (Fiss wrote his article in 1976) is constructed primarily to deal with the harms of over- and under-inclusiveness of "categorial"101 laws and policies. Second, many cases, both hypothetical and actual, that our intuition tells us raise issues of Equal Protection do not fit into that conceptual scheina.

According to Fiss, Equal Protection doctrine posits "antidiscrimination" as the inediating principle of the Equal Protection Clause. ${ }^{102}$ There are two important points here. First, the Equal Protection Clause must be interpreted via soine principle which gives it life and scope-thus the concept of a inediating principle. Second, the "anti-discrimination principle" has been that animating moral vision. Fiss means something quite specific by "anti-discrimination." To him, "discrimination" is classification and the "anti-discrimination principle" prohibits the harms of over-and under-inclusiveness of proxybased classification. He explains, "[t]he antidiscrimination principle-as I understand it, as Tussman and tenBroek designed it, and as the Supreme Court has generally used it-is a theory about ill-fit." ${ }^{103}$

Fiss and I agree that the Court's conception of wrongful discrimination is one of ill-fit. We agree that the "core idea-the foundational concept [is] ... one of means-ends rationality,"104 a conception that emphasizes whether the disputed classification is an acceptable way to achieve the purpose. Finally, we agree that equating the wrong the Equal Protection Clause ought to proscribe with the under- and overinclusiveness of categorial laws owes a great debt to Tussman and tenBroek. Interestingly, Fiss sees the Tussman and tenBroek conception of discrimination, which I call proxy discrimination, as truly synonymous with discrimination. He is then able to critique the link between

100. See Fiss, supra note 87 , at 84 .

101. I borrow this term from Frederick Schauer. His interest is in the relationship between classificatory ("categorial") laws and justice. Like me, Schauer believes that ill-fit does not capture everything that may be unjust about the use of categories in particular instances. See Frederick Schauer, Generality and Equality, 16 LAW \& PHlL. 279, 289 (1997).

102. See Fiss, supra note 87 , at 85 .

103. Id. at 94. This pairing of the Tussman and tenBroek article with the conception of wrongful discrimination as ill-fit is further evidence of the role Tussman and tenBroek played in cementing this conception.

104. Id. at 88 . 
discrimination and the Equal Protection Clause by showing that this narrow conception of ill-fit does not encompass all the harms that the Equal Protection Clause should cover.

While I agree with Fiss that this conception of Equal Protection is overly narrow, I do not think that an examination of fit between proxy and target exhausts the moral issues raised by classificatory laws. In other words, my debt to Fiss lies in his critique of the limitations of fit as a mediating principle of the Equal Protection Clause, but we part company at the point of his acceptance of Tussman and tenBroek's articulation of the harms of classificatory laws as equivalent with the harms of discrimination.

Fiss wants to substitute a "group disadvantage theory" for "antidiscrimination" as the mediating principle of the Equal Protection Clause. That is, he wants to move away from an emphasis on classification and its attendant moral issues in understanding the meaning of Equal Protection. In Fiss' view, "the state law or practice [that] aggravates (or perpetuates?) the subordinate position of a specially disadvantaged group"105 violates the Equal Protection Clause. Earlier, I said that Fiss' view is broader than my own. Fiss wants to enlarge the domain of wrongs that Equal Protection doctrine addresses to include nonclassificatory laws that reinforce social stratification. In my view, the doctrine ought to maintain its emphasis on classificatory laws. But it should also acknowledge and address the moral issues raised by those classificatory laws that are non-proxy in form.

\section{B. MacKinnon}

Catherine MacKinnon, like Fiss, criticizes the Court's antidiscrimination doctrine for its emphasis on inaccurate generalization as the primary harm to be eradicated. She sees the Court's doctrine as primed to handle the problem of stereotyping rather than subordination. In her view, the terrain of antidiscrimination law ought to be shifted. Rather than focusing on whether the sex-based categories employed in law fit reality, Equal Protection doctrine ought to ensure that women are not the social and economic inferiors of men.

In MacKinnon's view, stereotyping is not the problem. Even where a stereotype is inaccurate or irrational, the harm caused by the statute grounded on such a stereotype is broader than the harm of inaccurate characterization. ${ }^{106}$ Moreover, sometimes these stereotypes are accurate.

105. Id. at 134.

106. See Catherine A. MacKinnon, Reflections on Sex Equality Under Law, 100 YALE L.J. 1281, 1293 (1991) (arguing that "[a]s an account of the injury of discrimination, this notion of misrepresentation by generalization is certainly partial, limited, can be trivializing and even perverse"). 
But that does not legitimate the different and disadvantaging treatment of women they are used to support. Some accurate stereotypes are accurate precisely because women and men have in part been formed by the unfair practices of the past. So MacKinnon criticizes the Court's analysis of Reed v. Reed, ${ }^{107}$ in which the Court struck down an Idaho statute that gave a preference to male relatives over female relatives as estate administrators as overly narrow. Men in Idaho may well be better educated and possess other qualities that would make them, on average, better qualified to administer estates. But that is precisely the problem for MacKinnon. As she states in her characteristically emphatic way, "it is not only lies and blindness that have kept women down. It is as much the social creation of differences, and the transformation of differences into social advantages and disadvantages, upon which inequality can rationally be predicated." 108

Essentially, MacKinnon argues for a transformation in antidiscrimination law. Rather than being animated by a concern to treat like instances alike, what MacKinnon terms the differences approach, ${ }^{109}$ she thinks the doctrine ought to be animated by a concern with substantive equality of outcome, or the inequality approach. ${ }^{110}$ Like both Fiss and this Essay, MacKinnon sees current doctrine as largely grounded in a conception of wrongful discrimination as over-generalization or ill-fit. Individualized inquiry thus becomes the goal and the embodiment of fairness. She criticizes this vision both for its inability to recognize and remedy harms that are group harms, those which affect women as woinen, ${ }^{111}$ and for its blindness to the disadvantage that can be worked even through individualized inquiry. Instead, she offers: "A rule or practice is discriminatory, in the inequality approach, if it participates in the systematic social deprivation of one sex because of sex."112 The distinction between the Court's approach and MacKinnon's approach she puts succinctly: "The nemesis of the first approach is irrationality; the target of the second, subordination." 113

107. 404 U.S. 71 (1971).

108. Catharine A. Mackinnon, Sexual Harassment of Working Women 105 (1979).

109. See id. at 101-02 (arguing that "to prohibit sex discrimination is to prohibit not all differentiations between the sexes but only those that are seen as not well founded, that is, inaccurate or overgeneralized distinctions between the sexes. The test for discrimination is whether a rule or practice is irrationally grounded upon a sex difference").

110. See id. at 103 (explaining that the inequality approach sees "the prohibition on sex discrimination [as] aim[ing] to eliminate the social inferiority of one sex to the other, to dismantle the social structure that maintains a series of practices that cumulatively, in Owen Fiss' term, 'disadvantage' women").

111. MacKinnon raises the following question: "Will a law shaped to correct illusions rather than to confront the problems women have as women be able to face realities to the extent women have women's problems?" MacKinnon, supra note 106, at 1293.

112. MACKINNON, supra note 108, at 117.

113. Id. at 103. 
I agree with MacKinnon's basic insight that a conception of wrongful discrimination as stereotyping is an impoverished conception. Many problems of Equal Protection-the paradigm cases of de jure racial segregation among them-are simply not, at root, problems of inaccurate generalization. Disparate treatment based on accurate stereotypes can be harmful as well. ${ }^{114}$ Although I agree with MacKinnon that there is more to wrongful discrimination than inaccurate generalization, I disagree with her view that the problems of discrimination are never problems of stereotyping. MacKinnon wants to assimilate all Equal Protection cases under the inequality rubric, to ask in each case whether the law or policy works to subordinate a disadvantaged group. In my view, stereotyping is sometimes the problem. In cases in which the law or policy is an instance of proxy discrimination, an examination of the fit between proxy and target is morally relevant.

I also agree with MacKinnon that subordination is, at times, relevant to the moral inquiry in Equal Protection cases. In non-proxy cases, it is always a relevant inquiry whether the disadvantage worked by the classification tracks the pre-existing patterns of social advantage and disadvantage and thereby entrenches social stratification. But I disagree with MacKinnon's view that this exhausts the morally relevant issues of Equal Protection, even in non-proxy cases. In her view, all Equal Protection questions devolve into questions of group disadvantage. The analysis I propose is multifactoral. Equal Protection cases sometimes raise issues of accurate classification and stereotyping and sometimes require examination of the fairness to individuals, as well as to groups. At times the anti-caste principle that animates her moral vision will be dispositive, but at times other moral insights that speak also to Equal Protection will play a role in resolving the moral and legal issues raised.

\section{VI}

\section{A New Theory of Wrongful Non-Proxy Discrimination}

\section{A. The Theory Sketched}

A full and subtle account of when non-proxy discrimination is wrong and ought to be prohibited is a subject that requires an article of its own. Here I will sketch the three types of moral considerations that I

114. For example, battered women are not good health insurance risks because they are more likely than the average insured to need medical care in the future. However, the accuracy of the actuarial data on which the insurer relies (the rationality of the classification) does not justify denying health insurance coverage to battered women. We must ask why battered women are more likely to use health care than others. If the reasons for the use of health services results from injustice, I argue, then the insurer's reliance on the actuarial data will be morally troubling. For a more complete account of this problem and the moral issues it raises, see Deborah S. Hellman, Is Actuarially Fair Insurance Pricing Actually Fair?: A Case Study in Insuring Battered Women, 32 HaRv. C.R.-C.L. L. REv. 355 (1997). 
believe would play a role in such a theory. The explication of how these concerns together help us unravel the moral and legal permissibility of non-proxy discrimination I leave for another day.

First, Fiss and MacKinnon are correct: The subordination of disadvantaged social groups is a morally relevant concern. This anti-caste theory of Equal Protection taps a powerful intuition. If we believe that skin color and sex, for example, are unlikely to be correlated with less ability, then we must be suspicious of a society in which blacks and women consistently procure less of the social goods that society produces. It is likely that this pigmentocracy and sex-based hierarchy result from unfairness. History is relevant here. Where the distribution of benefits among socially defined groups tracks historical disadvantage, we must take care.

Second, we must also make sure that individuals are accorded their fair share of the benefits that society distributes and bear only their fair share of the burdens. So, if Virginia decides to provide university education funded by tax dollars, each Virginian must have the opportunity to get a fair share of this benefit. Now obviously what counts as a fair share is a difficult question. For example, one might question the fairness of spending tax dollars collected from all on higher education which benefits only a few, and a few drawn largely from the middle and upper classes. This may not be fair. John Rawls posits one plausible theory of when distributive rules are fair: Policies are fair so long as the inequality thereby produced benefits the least advantaged members of the society. ${ }^{115}$ This is a tough test to meet. Clearly there are other possibilities. I propose the following: Classificatory rules are fair so long as the process by which they were enacted was democratic and no minority, group affected was bereft of voice or power. ${ }^{116}$

Some species of process-based view best captures the sense of fairness relevant here. ${ }^{117}$ Society ought to be able to create a diverse array of options and benefits. To hold that Equal Protection requires sameness of treatment overly constrains the creative power of our communities to offer myriad opportunities for members. So, for example, single-sex education may well be enriching. To provide it requires the exclusion of

115. See JOHN RAWLS, A THEORY OF JUSTICE 75-83 (1971).

116. John Hart Ely has a process-based conception of democratic fairness along these lines. See, e.g., ELY, supra note 88.

117. Of course, Rawls' own view of justice is a process-based conception. Rawls' theory of justice as fairness is often termed a form of "pure procedural justice," meaning that so long as the choice situation is itself fair (Rawls" "original position"), then whatever distributional rules it produces are fair. See R Aws, supra note 115, at 85-86. At this point, I do not endorse any particular process-based conception of when classificatory laws distributing benefits and burdens are in fact fair. Rather, I only assert that attention must be paid to the faimess of the distribution of benefits and burdens accomplished by the classification; unpacking what "fairness" requires likely relies on a process-based conception. 
one sex from that particular educational opportunity. This is clear nonproxy sex discrimination. Part of the analysis of whether state-supported single-sex education is permissible will thus require discussion of whether the decision to spend tax dollars in this way was fairly reached.

Third, an inquiry into the moral and legal permissibility of instances of non-proxy discrimination should include attention to the social significance of the state's classificatory practice. As Brown made clear, social practices have expressive significance which cannot be ignored. Black school children and their parents could not simply read Kansas' school-segregation law any way they chose; social meaning is collectively produced. ${ }^{118}$ When the state employs classifications in its laws and policies, it must pay attention to the message it sends and thereby condones.

These three concerns are clearly interrelated. Perhaps on further investigation they will be revealed to grow from a single root. Further inquiry will require untangling this interrelatedness and determining their relative weight.

\section{B. New Theory: As Applied to United States v. Virginia}

In order to get a sense of how my theory of non-proxy discrimination would change the way the Court would address non-proxy cases, it is helpful to reexamine United States v. Virginia. According to the nonproxy theory I outline above, courts should consider three questions. First, flowing from the anti-caste understanding of the Equal Protection Clause, courts should determine whether the law or policy disadvantages a historically maltreated social group, thereby entrenching social hierarchy by group or class. Second, courts should look at whether the individuals excluded by the classificatory policy can claim they do not have access to their fair share of societal resources. And, third, courts should be sensitive to the expressive significance of the discriminatory statute.

The exclusion of women from VMI clearly does disadvantage women, who, as a group, have been wrongfully denied opportunities and rights in the past on the basis of being women. The opportunity to attend VMI offers significant rewards in terms of future career options, social status, and earning potential, as the record in the case makes clear. ${ }^{119}$ Thus, to cut women off from the opportunity to attend VMI would track a caste distinction already present in society, that of men over women, and possibly further entrench it. This provides a reason, though not a dispositive one, to strike down the male-only admissions policy of the state-supported VMI.

118. For an account of the common character of "social meaning," see Lessig, supra note 17.

119. See United States v. Virginia, 116 S. Ct. 2264, 2285 (1996). 
This inquiry into whether the classification is used to disadvantage a socially marginalized group bears some similarity to the moral and legal intuition behind the current doctrine's focus on whether a classification is "suspect" or "quasi-suspect." This determination is based, at least in part, on whether the group thereby defined has suffered a history of wrongful discrimination. ${ }^{120}$ In other words, the history of wrongful discrimination on the basis of race requires that current classifications on the basis of race be carefully scrutinized.

My view differs from the Court's in two important respects. First, and most significantly, since the concern with history in my account derives from an anti-caste principle, only those classifications that disadvantage a historically disadvantaged group require heightened inquiry. Thus affirmative action or benign race and sex discrimination would not be morally problematic on this basis, though each may raise individual fairness or expressive significance concerns.

Second, current Equal Protection doctrine draws a bright line between those classifications that require "strict scrutiny," "intermediate scrutiny," and rational basis review. In my view, there is no need for the starkness of three rigid categories. Rather, the inquiry need only be whether the classification in a statute disadvantages a group that is currently overrepresented in the lower socio-economic classes, thereby entrenching and supporting caste distinctions. If the classification does so a little, that provides a reason, albeit weak, to oppose it. If the classification does so a lot, this is a strong reason to strike it down. ${ }^{121}$

In assessing the moral and legal permissibility of VMI, we must next look at whether Virginia's support of VMI deprives Virginian women of their fair share of the state's education dollars. Although I have not here put forward a full account of what fairness requires, I believe the right conception of fairness embedded in Equal Protection is process-based. Therefore, attention should focus on whether women have been full participants in the democratic processes in play, which directly affect the allocation of funding to VMI.

Third, a non-proxy inquiry requires that one look at what message state funding of a men-only military college is likely to send to the men and women of Virginia. Because there is no alternative military training

120. See, e.g., San Antonio Sch. Dist. v. Rodriguez, 411 U.S. 1, 28 (1973) (characterizing the "traditional indicia of suspectness" as being "saddled with . . . disabilities, or subjected to . . . a history of purposeful unequal treatment, or relegated to ... a position of political powerlessness").

121. Justice Marshall has advocated a similar view. See Rodriguez, 411 U.S. at 98 (Marshall J., dissenting) (explaining his view that the Court should adopt a "spectrum of standards" in reviewing alleged Equal Protection violations, which should reflect both "the constitutional and societal importance of the interest adversely affected and the recognized invidiousness of the basis upon which the particular classification is drawn"); see also Dandridge v. Williams, 397 U.S. 471, 508 (1970) (Marshall J., dissenting). 
$\therefore$ school for women, state support of VMI may appear to endorse the view that the military is a career suitable only for men. Alternatively, since VMI's mission statement defines its purpose as training "citizensoldiers" and only a small number of its graduates do pursue military careers, one could interpret state support of the male-only VMI as endorsing the following message: Men benefit from an adversarial inethod of education, women do not. Both of these messages are worrisome messages for the state to support, the former significantly more so than the latter. Note here that what is wrong with state endorsement of a message about women's abilities to successfully pursue a military career or to thrive in a belligerent educational environment has little to do with the inexactness of the stereotype on which such views are based. Rather the problem lies in state endorsement of such a message, even if largely accurate, given our society's public commitunent to aiming at state neutrality ${ }^{122}$ on such issues. The problem is not one of accuracy (as the concern with fit endemic to the Court's current Equal Protection doctrine would suppose), but instead one of ensuring that the state does not weigh in on one side of a debate about the nature of women and men.

Taking these three inquiries together, the stronger argument lies on the side of forbidding Virginia's support of VMI. More important than the resolution of the case are the reasons upon which the non-proxy theory rests. Compare them to the Court's rationale. Justice Ginsburg's opinion in United States $v$. Virginia focused on the looseness of the fit between the classification "men" and the class of persons who would thrive in the VMI atmosphere and succeed in becoming the "citizensoldiers" that the school hopes to produce. The constitutional problem for Ginsburg is that "neither the goal of producing citizen-soldiers,' VMI's raison d'être, 'nor VMI's implementing methodology is inherently unsuitable to women." "123 Because some women can and want to complete the VMI curriculum, the school's single-sex admissions policy is constitutionally flawed.

This analysis both misconstrues VMI's purpose in restricting admissions to men and focuses the legal inquiry on the wrong moral concerns. VMI does not limit admissions to men as a means of efficiently

122. There has been much criticism in the academic literature of the alleged neutrality of the state. Some of the criticism focuses on blatant lapses from neutrality, some on the possibility of ever attaining neutrality. This debate is part of the general critique of liberalism. I hope to skirt that debate here (though I do consider myself a liberal). I believe we ought to be wary of strong state endorsement of controversial political views. This position can be supported either by a commitment to the goal of state neutrality (classic liberalism of rights) or by a commitment to liberalism as a substantive view (a liberalism of the good). On this view, the only messages that the state may endorse are liberal ones, messages which support and encourage community members in the exercise of their ability to choose life plans and values of their own.

123. United States v. Virginia, 116 S. Ct. 2264, 2279 (1996) (quoting the court of appeals opinion in the case, 976 F.2d 890, 896 (4th Cir. 1992)). 
admitting the students who will make the best citizen-soldiers. VMI admits only men because of the perceived educational value of the singlesex environment. The Court's mischaracterization of the policy's purpose makes the opinion seem largely irrelevant. The doctrine, rather than the facts, is driving the inquiry. Instead, the moral and legal permissibility of VMI should turn on whether the male-only policy further entrenches the relative social position of men and women, on whether women in Virginia will get a fair share of the state's educational resources if state support of VMI is permitted, and on whether state support of a male-only military school with an adversarial teaching method sends too strong and one-sided a message ${ }^{124}$ about what men are like and how they differ from women.

\section{VII \\ THE EFFECTS OF RECLASSIFICATION}

A new non-proxy theory capable of distinguishing between permissible and impermissible instances will have two important effects. First, such a theory will force the Court to articulate what makes nonproxy discrimination wrong in those instances where the Court finds it so. This will require the Court to address the real moral and legal issues on which cases like United States $v$. Virginia and Romer rest. Second, because a new non-proxy theory focuses the Court's attention on different questions, some familiar debates will be recast.

\section{A. Addressing the Real Issues}

Recognizing the conceptual distinction between proxy and nonproxy discrimination would force the Court, commentators, and the public to debate and attempt to resolve the real issues. If the permissibility of state-supported single-sex education at VMI depends on the factors outlined above, then the Court ought to be offering us a resolution of these issues. Rather than telling us that some women will thrive at VMI and therefore Virginia's support of the school violates Equal Protection, the Court should examine whether state support of VMI constitutes too powerful an endorsement of a particular conception of women and men to pass constitutional muster.

124. Perhaps we should screen illiberal messages. A message is "illiberal" if it expresses a view inconsistent with liberalism's assertion that each person should be able to freely choose her own life goals and values. Thus, the claim that only men belong in the military is illiberal because it is inconsistent with the liberal view that a woman who chooses soldiering as her life plan should be able to pursue it. 


\section{B. Possible New Avenues: Affirmative Action}

In addition to forcing the courts and the public to look at the real issues on which non-proxy cases turn, a new theory for non-proxy cases may also allow us to see some familiar debates in new terms. The moral and legal defensibility of affirmative action provides a good example. Recognition of non-proxy discrimination as a distinct form of discrimination which necessitates its own analysis may provide more legal leg room for affirmative action initiatives. Because the conception of discrimination which dominates our public and legal consciousness is a conception of proxy discrimination, when courts look at affirmative action policies, they instinctively ask what the racial proxy is targeting. Because racial classifications are viewed as suspect, even when used for benign purposes, the targets for which the racial proxy may be used are limited to those in which the correlation between target and proxy is especially strong. As a result, affirmative action is likely to be upheld in extremely limited situations. ${ }^{125}$

At present, affirmative action is permitted in cases where the racial proxy aims at either of two targets, one of which may soon be repudiated. In affirmative action initiatives, race may be used as a proxy for victim of past discrimination in the same locale and same job field ${ }^{126}$ and in the educational setting as a proxy for diversity. ${ }^{127}$ The Supreme Court has explicitly rejected affirmative action plans in which race is used as a proxy for victim of general societal discrimination, on the grounds that in those instances there is too much slippage between the classification and the target. ${ }^{128}$

These are narrow grounds. Moreover, in the educational context, even the Powell opinion in University of California Regents v. Bakke $e^{129}$ limits this use of race to a "plus-factor" that must be weighed with and against other kinds of proxies for diversity, such as hometown or economic status. For Powell, the Equal Protection Clause demands individualized selection when determining admission to medical school or college. "[T]he principal evil of [the University of California's] special admissions program," a program that reserved 16 slots in the medical school class for minority applicants, was that it denied to white applicants the "right to individualized consideration without regard to ... race." 130 Moreover, if the holdings of the 5th Circuit's opinion in

125. Fiss provides an excellent account of how the conception of discrimination as ill-fit will almost always damn a plausible state objective. See Fiss, supra note 87, at 107-08.

126. See Richmond v. J. A. Croson Co., 488 U. S. 469 (1989).

127. See University of California Regents v. Bakke, 438 U. S. 265 (1978).

128. See Adarand Constructors, Inc. v. Pena, 515 U.S. 200 (1995).

129. 438 U.S. at 265 .

130. Id. at 270 n. 16 . 
Hopwood v. Texas ${ }^{131}$ are adopted-repudiating Powell's admission of diversity as a legitimate target-the narrow ground on which permissible affirmative action now rests will shrink further.

Recognizing that affirmative action is often adopted as non-proxy discrimination may widen this berth. In what follows, I do not intend to assert that affirmative action is morally or legally justified. Rather, my claim is that courts have not adequately addressed this question because current Equal Protection doctrine impedes that inquiry. Diversity is a complex goal. At times, diversity is the target of the racial proxy, and at times it is the rationale for a non-proxy sorting on the basis of race. This labeling difference is significant. If race is used as a proxy for diversity, the target, usually experiential diversity (Bakke) or viewpoint diversity (Metro Broadcasting), is diversity of another sort. Because racial classifications are subject to strict scrutiny, this use of racial diversity as a surrogate for diversity of experience or viewpoint will generally be too loose to pass constitutional muster. ${ }^{132}$ If instead, we see that racial diversity itself is often the reason for a racial preference, different questions are raised. These are questions not of fit, but of justification.

In the present doctrinal climate, we do not see this aim-seeking racial diversity itself-as even plausibly constitutionally legitimate. As non-proxy racial discrimination, it is the paradigmatic Equal Protection violation. For example, when Justice Powell rejects as illegitimate the University of California's objective of "reducing the historic deficit of traditionally disfavored minorities in medical schools and the medical profession," ${ }^{133}$ the non-proxy basis for the racial preference at issue in Bakke, he does so categorically:

If petitioner's purpose is to assure within its student body some specified percentage of a particular group merely because of its race or ethnic origin, such a preferential purpose must be rejected not as insubstantial but as facially invalid. Preferring members of any one group for no reason other than race or ethnic origin is discrimination for its own sake. This the Constitution forbids. ${ }^{134}$

Such "discrimination for its own sake," rather than for the sake of some target of the racial proxy, is similarly the subject of an unequivocal rejection in the 5th Circuit's opinion in Hopwood v. Texas: "The

131. 78 F.3d 932 (5th Cir. 1996), cert. denied, 116 S. Ct. 2581 (1996) (rejecting diversity as a compelling governmental interest and rejecting the classification of race as sufficiently narrowly tailored to the achievement of viewpoint or experiential diversity).

132. The racial preference upheld in Metro Broadcasting was subject to intermediate scrutiny. I am assuming that were it subject to strict scrutiny, as would be required today under Adarand, Metro's preference scheme would be struck down.

133. Bakke, 438 U.S. at 305.

134. Id. at 307. 
use of race, in and of itself, to choose students simply achieves a student body that looks different. Such a criterion is no more rational on its own terms than would be choices based upon the physical size or blood type of applicants." 135 But is it so irrational for the state law school in Texas to care about having a racially diverse class? While unsure of the answer, I am confident that this is a question that should not be dismissed outright. Rather, it needs a richly developed doctrine of constitutionally permissible non-proxy discrimination to address it.

The new non-proxy theory I endorse would analyze the constitutionality of the law school's admissions practice by asking whether the policy disadvantages a historically disadvantaged group, whether it is unfair to the individuals adversely affected, and whether the message of this state policy is inimical to liberal values. In this case, as in all instances of affirmative action, the discriminatory policy would not entrench existing patterns of social disadvantage. Rather, such policies work to uproot these patterns. The anti-caste principle which I believe makes up a part of the moral foundation of the Equal Protection Clause is unlikely to be offended in instances of affirmative action.

The theory also requires that the policy be fair to the individuals adversely affected. Here, we must ensure that Cheryl Hopwood and the other mostly white students judged using the more demanding admissions criteria were fairly treated. Fairness, in this context, is a processbased conception. A court must ask whether Hopwood and the others had adequate voice and vote in the political process responsible for the affirmative action policy.

Finally, a court should examine the message conveyed when a state law school employs different admissions criteria for African Americans and Mexican Americans on the one hand and white and other minorities on the other. Two different interpretations seem plausible. First, the social meaning of such affirmative action may be stigma. The policy may be read to imply that the benefited groups have less ability than whites. Alternatively, the social meaning of the practice could be to reaffirm that past discriminatory practice and ongoing stereotyping continues to affect African Americans and Mexican Americans significantly. On this readimg, affirmative action works to counteract these powerful social forces.

Affirmative action probably carries both of these meanings today. In order to determine whether the non-proxy-based discrimination employed by the law school is constitutional, we must thus weigh all three of the factors discussed above. While a court need not worry about entrenching social disadvantage, it must consider whether the process by which this admissions practice was adopted was fair and whether the

135. Hopwood, 78 F.3d at 945 . 
stigma produced by government endorsement of varying admissions criteria for different racial groups is significant enough to threaten liberal values.

Current doctrine forces us to ask only a cramped and circumscribed question: When may racial proxies be used to target viewpoint or experiential diversity? Because race is often not a good proxy for viewpoint and often not tight enough a proxy for experience, these programs often fail constitutional scrutiny, and rightly so if the racial classification must be defended as a proxy. In fact, the legitimization of race as a good proxy for other traits itself causes harm by further entrenching those stereotypes we seek to erode. A non-proxy theory of discrimination offers an opportunity to ask a different and important question: When may the state seek racial diversity itself? We answer that question by looking at the three considerations that make up the outline of the non-proxy theory we must now develop: reinforcing caste stratification, unfairness to individuals, and the social meaning of the practice.

\section{ConCLusion}

In this Essay, I have argued for three claims. First, there is an important conceptual distinction between classificatory laws which aim at the separation achieved by the classification itself, non-proxy discrimination, and classificatory laws which aim at a related but different sorting, proxy discrimination. Second, the Supreme Court's Equal Protection doctrine, viewed as a theory of when discrimination is wrong, offers an account that only suits cases of proxy discrimination. Third, as a result of this limitation, the Court lacks the doctrinal equipment to analyze non-proxy cases properly. The Court's treatment of these nonproxy cases consequently fails to address the relevant moral concerns which should form the basis of this analysis.

The Court must recognize that the current doctrine is not useful for non-proxy cases. A new theory is required. First, courts must ask whether the class of people disadvantaged by the statute in question is a class historically disadvantaged in our society-the anti-caste principle. Second, courts must ask whether the allocation of benefits and burdens created by the statute is fair to individuals. And, third, courts must examine the inessage embedded in the classification for consistency with the liberal values of choice and self-determination. Together, these three factors describe the beginning of a theory for non-proxy discrimination. Because this new theory substitutes non-instrumental concerns for the Court's current fixation on fit, it dramatically recasts the analysis of familiar and unfamiliar Equal Protection probleins. 
CALIFORNIA LAW REVIEW 